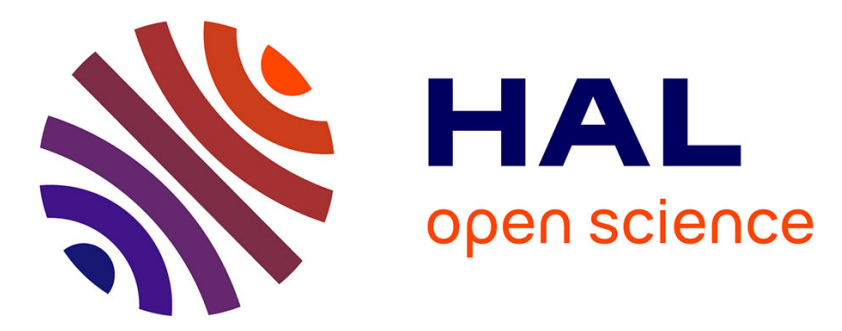

\title{
Interaction of magma with sedimentary wall rock and magnetite ore genesis in the Panzhihua mafic intrusion, SW China
}

Clément Ganino, Nicholas Arndt, Mei-Fu Zhou, Fabrice Gaillard, Catherine

Chauvel

\section{To cite this version:}

Clément Ganino, Nicholas Arndt, Mei-Fu Zhou, Fabrice Gaillard, Catherine Chauvel. Interaction of magma with sedimentary wall rock and magnetite ore genesis in the Panzhihua mafic intrusion, SW China. Mineralium Deposita, 2008, 43, pp.677-694. 10.1007/s00126-008-0191-5 . hal-00352271

\section{HAL Id: hal-00352271 https://hal.science/hal-00352271}

Submitted on 12 Jan 2009

HAL is a multi-disciplinary open access archive for the deposit and dissemination of scientific research documents, whether they are published or not. The documents may come from teaching and research institutions in France or abroad, or from public or private research centers.
L'archive ouverte pluridisciplinaire HAL, est destinée au dépôt et à la diffusion de documents scientifiques de niveau recherche, publiés ou non, émanant des établissements d'enseignement et de recherche français ou étrangers, des laboratoires publics ou privés. 


\section{Interaction of magma with sedimentary wall rock and}

\section{magnetite ore genesis in the Panzhihua mafic}

\section{intrusion, SW China}

Clément Ganino $^{1}$, Nicholas T. Arndt ${ }^{1}$, Mei-Fu Zhou ${ }^{2}$, Fabrice Gaillard ${ }^{3}$ and Catherine

Chauvel $^{1}$

${ }^{1}$ Laboratoire de Géodynamique des Chaînes Alpines, Université Joseph Fourier de Grenoble, CNRS, 1381 rue de la piscine 38400 Saint Martin d'Hères, France

${ }^{2}$ Department of Earth Sciences HKU, Pokfulam road, Hong Kong, China

${ }^{3}$ Institut des Sciences de la Terre d'Orléans, CNRS, la rue de la férollerie 45071 Orléans

CEDEX 2, France

Corresponding author

Clément Ganino

Laboratoire de Géodynamique des Chaînes Alpines, Université Joseph Fourier de Grenoble, CNRS, 1381 rue de la piscine 38400 Saint Martin d'Hères, France

$$
\begin{aligned}
& \text { Tél : +33-4-76 } 514073 \\
& \text { Fax : +33-4-76 } 514058
\end{aligned}
$$

Email : clement.ganino@ujf-grenoble.fr 


\section{Abstract}

In SW China, several large magmatic Fe-Ti-V oxide ore deposits are hosted by gabbroic intrusions associated with the Emeishan flood basalts. The Panzhihua gabbroic intrusion, a little deformed sill that contains a large titanomagnetite deposit at its base, concordantly intrudes lateProterozoic dolostones. Mineralogical and chemical studies of the contact aureole in the footwall dolostones demonstrates that the metamorphism was largely isochemical, but for the release of large quantities of $\mathrm{CO}_{2}$ as the rocks were converted to marble and skarns during intrusion of the gabbroic magma. Petrological modelling of the crystallization of the intrusion, using $\mathrm{H}_{2} \mathrm{O}$-poor Emeishan basalt as parent magma, shows that under normal conditions Fe-Ti-oxides crystallize at a late stage, after the crystallization of abundant olivine, clinopyroxene and plagioclase. In order for titanomagnetite to separate efficiently to form the ore deposit, this mineral must have crystallized earlier and close to the liquidus. We propose that $\mathrm{CO}_{2}$-rich fluids released during decarbonatization of sedimentary floor rocks passed up through the magma. Redox equilibria calculations show that when magma with the composition of Emeishan basalt is fluxed by a $\mathrm{CO}_{2}$-rich gas phase, its equilibrium oxygen fugacity ( $\mathrm{fO}_{2}$ ) increases from FMQ to FMQ+1.5. From experimental constraints on magnetite saturation in basaltic magma under controlled $\mathrm{fO}_{2}$, such an oxidizing event would allow magnetite to crystallize near to the liquidus, leading to the formation of the deposit.

Keywords : magma, sediment, magnetite ore, oxygen fugacity, skarn

\section{Introduction}

The Emeishan large igneous province covered more than a million $\mathrm{km}^{2}$ in southwest China when it was emplaced about 258 m.y. ago (Zhou et al. 2002a). Its age coincides with Guadalupian mass extinction and several authors (Courtillot et al. 1999; Wignall 2001) have suggested that the flood volcanism at least contributed to this event. Several large magmatic Fe- 
Ti-V oxide ore deposits occur as discordant lenses in the lower part of gabbroic layered intrusions that are associated with the Emeishan flood basalts (Zhou et al. 2005).

The Panzhihua gabbroic intrusion is a sill-like body that dips $50-60^{\circ} \mathrm{NW}$ and extends about $19 \mathrm{~km}$ along strike. Layers and discordant pods and veins of Ti- and V-rich magnetite in the lower part of the intrusion have been exploited in open pit and underground mines since the 1960s, providing excellent exposure of the geological units. The gabbroic body intruded late Proterozoic dolostones, marlstones and sandstones, transforming them into brucite, forsterite- or diopside-bearing marbles in a more than $300 \mathrm{~m}$-thick contact aureole at the base of the intrusion. Rare xenoliths of the same rocks are dispersed through the lower part of the intrusion.

In this paper we report the results of a petrologic and geochemical study that focused on the marbles in the contact aureole. New chemical data and numerical modeling of the magma crystallization have allowed us to gain a better understanding of how the interaction between magma and sedimentary rocks influenced the magmatic evolution of the gabbroic intrusion and associated syenites. In addition, our estimates of the amount of $\mathrm{CO}_{2}$ and other gases released from the aureole provide the basis of a new model for the formation of the Fe-Ti ores and some measure of the possible environmental impact of the Emeishan magmatic event.

\section{Geologic background}

\section{Regional Geology}

Southwestern China comprises part of the Yangtze Block to the east and part of the Tibetan Plateau to the west (Fig. 1). In the western part of the Yangtze Block, where the Emeishan basalts erupted, Mesoproterozoic granitic gneisses and metasedimentary rocks are intruded by Neoproterozoic ( 800 Ma) arc-related granites (Zhou et al. 2002b) and overlain by a series of Neoproterozoic ( 600 Ma) to Permian marine and terrestrial strata. During the Cenozoic, the western part of the Yangtze block was subjected to strike-slip faulting and thrusting while the eastern part was dominated by block-faulting and shallow level shearing (Burchfiel et al. 1995). 
The Neoproterozoic Era (1000-542 Ma) in southwest China is divided into three systems, the Qingbaikou (1000-800 Ma), Nanhua (800-680 Ma) and Sinian systems (680-542 Ma). The Nanhua system (Fig. 2a) is subdivided into the Nantuo formation (coarse sandstone and glacial deposits), Datangpo (siltstone, mudstone and limestone), Gucheng (tillite), and Liantuo formations (sandstone with volcanic clasts), although in places the latter formations are sometimes absent. The Sinian system is divided into the overlying Dengying formation, which is usually 500 meters thick and composed of an upper unit of grey and white thick, layered dolostones, a middle unit of greyish, moderately thick layered cherty dolostone, and a lower unit of light-colored dolostone, and the underlying Doushantuo formation, which is locally up to 800 meters thick and is mainly composed of conglomerate, sandstone and shale with thin dolostone layers (Liu 1991).

\section{Emeishan Large Igneous Province}

The Emeishan Large Igneous Province consists of flood basalts and related intrusions of Late Permian age considered by Chung and Jahn (1995) to be linked to the initiation of a mantle plume event (Fig. 1). Major deformation and uplift related to Himalayan tectonics has disrupted the plateau, a large portion of which has been lost through erosion. The Emeishan basalts are found mainly in southwestern China, but also far to the south in Vietnam (Tien 2000), having been displaced by the Red River fault zone. Based on the study of petroleum drill cores in the Sichuan basin and on the recognition of feeder dykes in the Yuanmou-Xichang region, Zhou et al. (2002a) estimated that the flood basalts initially covered an area of more than 5 million $\mathrm{km}^{2}$. The thickness of the basalt package ranges from a few hundred meters up to $5 \mathrm{~km}$ and the original volume could have been more than $1 \mathrm{Mkm}^{3}$ (Xu et al. 2001; Chung et al. 1998; Song et al. 2001; Song et al. 2004).

The Emeishan basalts overlie the Early Permian Maokou Formation and are in turn overlain by the Late Permian Xuanwei and Wujiaping formations. These stratigraphic relationships 
suggest that the Emeishan traps erupted near the end of the Guadalupian, a result confirmed by radiometric age dating (Zhou et al. 2002a).

The volcanic rocks of the Emeishan consist mainly of basalts with minor picrites. The basalts display a range of $\mathrm{SiO}_{2}$ (43.6 wt $\%$ to $\left.52.1 \mathrm{wt} \%\right), \mathrm{Al}_{2} \mathrm{O}_{3}(5.0$ to $12.6 \mathrm{wt} \%)$ and total alkali $\left(\mathrm{K}_{2} \mathrm{O}+\mathrm{Na}_{2} \mathrm{O} ; 0.7 \mathrm{wt} \%\right.$ to $\left.6.5 \mathrm{wt} \%\right)$ contents (Song et al. 2001). $\mathrm{MgO}$ contents range from high in the picrites $(25 \mathrm{wt} \%)$ down to values of $7-8 \mathrm{wt} \%$ in the basalts, indicating that these magmas evolved through fractional crystallization after separation from their mantle source. A lack of $\mathrm{Nb}-\mathrm{Ta}$ anomalies and an absence of correlation between trace element ratios such as $\mathrm{Nb} / \mathrm{La}$ and $\mathrm{Sr}$ or $\mathrm{Nd}$ isotopic compositions suggest that crustal contamination was minimal. Initial isotopic ratios $\left({ }^{143} \mathrm{Nd} /{ }^{144} \mathrm{Nd}=0.51229-0.51276\right.$ and $\left.{ }^{87} \mathrm{Sr} /{ }^{86} \mathrm{Sr}=0.70480-0.70647\right)$ imply that the basalts were derived from a homogeneous source with composition near that of primitive mantle (Song et al. 2001).

\section{Gabbroic intrusions of the Panxi region}

In the Panxi region, uplift and erosion along north-south trending faults has exposed mafic dykes and large layered mafic-ultramafic intrusions. Zhou et al (2008) obtained U-Pb zircon ages of 259 to $263 \mathrm{Ma}$ for these intrusions and used the coincidence with the ages of Emeishan volcanism to conclude that the intrusive and volcanic rocks formed parts of the same magmatic province. Some of the larger intrusions, such as Panzhihua which is $\sim 19 \mathrm{~km}$ long and $\sim 2 \mathrm{~km}$ thick, are near-concordant and distinctly layered, and several contain large oxide deposits. Three such intrusions and their ore deposits have been described by Lu et al. (1988) and Ma et al. (2003). The Panzhihua deposit contains 1333Mt of ore grading $43 \mathrm{wt} \% \mathrm{FeO}, 12 \mathrm{wt} \% \mathrm{TiO}_{2}$ and $0.3 \mathrm{wt} \% \mathrm{~V}_{2} \mathrm{O}_{5}$ (Ma et al. 2003), and is currently being mined. The other deposits are larger Baima contains 1497 Mt and Hongge contains 4272 Mt (Ma et al. 2003) - but they are not yet exploited.

All three intrusions are approximately concordant and intrude at the contact between dolostones of the Doushantuo Formation (Fig. 3) and overlying Emeishan basalts and dacites or Mesozoic sedimentary formations. Large syenitic complexes were spatially emplaced higher in 
the stratigraphy than the gabbroic intrusions. The syenitic intrusions are $\sim 10 \mathrm{~km}$ long, $\sim 2 \mathrm{~km}$ wide and $\sim 2 \mathrm{~km}$ thick and consist of homogeneous, fine-grained rock containing microcline, pyroxene, hornblende, quartz, biotite and minor apatite At Panzhihua, the upper contact between syenite or Triassic silts and the mafic intrusion is faulted (Figure 2b). Shellnutt and Zhou (2007) provide a detailed description of the geological and petrological characteristics of a similar association of a gabbroic body and a syenite at Baima, $80 \mathrm{~km}$ to the NNW.

\section{Petrology of the Panzhihua gabbroic layered intrusion}

The Panzhihua mafic layered intrusion dips $50-60^{\circ} \mathrm{NW}$ and extends about $19 \mathrm{~km}$ along strike in a NE-SW direction (Fig. 3). Despite the regional tectonic activity, the intrusion is largely undeformed. As seen in Figure 2c, it is differentiated from a lower series of layered melanogabbros, through a middle series of normal gabbros, to an upper series of leucogabbro (Zhou et al. 2005).

The gabbros are generally medium- to coarse-grained and contain plagioclase, clinopyroxene, magnetite, olivine and amphibole, as described in detail in Lu et al. (1988) and Zhou et al. (2005). The proportions and types of oxide minerals vary through the intrusion. Four zones are described by Zhou et al. (2005) (Fig. 2c). The marginal zone at the base of the intrusion consists of a $40 \mathrm{~m}$ thick heterogeneous unit with fine-grained hornblende-bearing gabbro and olivine gabbro and contains numerous marble xenoliths derived from the wall-rock (Zhou et al. 2005). The lower zone $(0-110 \mathrm{~m})$ is a well-layered melanogabbro containing major oxide layers up to $60 \mathrm{~m}$ thick. Massive ores typically contain $>80 \%$ titanomagnetite. The middle zone is up to $800 \mathrm{~m}$ thick and consists of layered gabbro with minor oxide ore bodies. The upper zone, with a thickness of 500-1500 m, consists mainly of weakly mineralized leucogabbro. The uppermost zone of the intrusion is not as well layered as the middle and lower zones and contains notably less oxide. The magmatic layers in the middle and lower zones vary in frequency and dimension from centimetre- to decimetre-scale (Zhou et al. 2005). Modal layering, defined by changes in the proportions of dark and light minerals, is superimposed on 
textural layering defined by differences in the size and the orientations of the dominant cumulus minerals, mainly pyroxene and plagioclase. Many layers are graded, with larger grains at the base of the each layer (Zhou et al. 2005). Grain size variation is visible at the intrusion scale as well in that coarser minerals dominate in the lower zone of the intrusion. Several rocks contain igneous lamination due mainly to the alignment of tabular plagioclase grains. The middle zone is rich in apatite (up to 5\%), whereas the lower zone is characterized by abundant Fe-Ti oxides. Several anorthositic dykes cut the middle and upper zones and syenitic and leucogabbro dykes, roughly 1-2 m wide and several metres long, cut the lower zone. Olivine is a rare mineral even in the lower zones of the intrusion.

On the basis of their mineralogical observations, Zhou et al. (2005) proposed that the crystallization began with minor olivine, followed by clinopyroxene and plagioclase and finally amphibole, titanomagnetite and sulphide. Pang et al. (2008a) recently identified Fe-Ti oxide as inclusions in olivine and clinopyroxene, an observation that led them to conclude that magnetite had in fact crystallized at an early stage of the solidification of Panzhihua intrusion.

Both layered and lens-shaped ore bodies are found within the Panzhihua intrusion. Small lenticular bodies, up to $160 \mathrm{~m}$ long and $30 \mathrm{~m}$ wide (Zhou et al. 2005), are found mostly in the middle unit. Larger bodies of layered ore are restricted to the basal part of the lower unit. The major ore zone is continuous for about $15 \mathrm{~km}$ along strike. The quality of the ore is heterogeneous, in some places consisting of disseminated magnetite and in others forming massive ore containing more than $50 \%$ magnetite. The mineralogy of the rocks of the Panzhihua intrusion and the magmatic ores have been described by Lu et al. (1988) and Zhou et al. (2005).

\section{Sampling and analytical procedures}

\section{Sampling}

A total of 133 samples of sedimentary rocks, skarns and magmatic rocks were collected during field trips in June and December 2005. The sampling focused on the contact aureole at the 
lower margin of the intrusion because the hanging wall is in fault contact with a syenite). We collected a total of 32 samples of marbles and skarns, 15 at the northern end of the intrusion, where the open pit provides excellent outcrop, and an additional 4 samples (the sample EM39 shown in Figure 4e, and the samples EM107, EM108 and EM109) along a $450 \mathrm{~m}$ long traverse extending into the meta-sandstone at the margin of the aureole, as shown on Figure 3. A further 13 samples were collected in the centre and at the southern end of the intrusion, including 6 in a quarry located about $7 \mathrm{~km}$ SSW of Panzhihua. Samples collected in the northern and southern parts of the aureole are very similar in mineralogy and texture.

We also collected 14 samples of unmetamorphosed Sinian sedimentary rocks at locations far from the intrusion. Samples EM34 and EM36 were sampled next to the Ertan dam $22 \mathrm{~km}$ to the north of Panzhihua, and 6 samples, EM87 to EM92, were sampled in a roadcut $12 \mathrm{~km} \mathrm{NW}$ of Panzhihua (Fig. 3).

Polished thin sections were used for petrographical description of the rocks and for the microprobe analyses. Representative samples were crushed in a steel jaw crusher and powdered $(<80 \mu \mathrm{m})$ in an agate mill for chemical analyses.

\section{Electron microprobe and scanning electron microscope analyses}

Mineral analyses were performed using a LEICA Stereoscan 440 scanning electronic microscope at the University of Chambery (France). Electron microprobe analyses reported in Table 1 were obtained using a CAMECA SX50 electron microprobe at the University of Lausanne (Switzerland), with natural minerals as standards. The beam diameter was $\sim 2 \mu \mathrm{m}$; the acceleration voltage $15 \mathrm{kV}$, the beam current $15 \mathrm{nA}$ and counting time $30 \mathrm{~s}$.

\section{Major- and trace-element analyses}

Major element oxide concentrations were measured by the CRPG Nancy, France, using a Jobin-Yvon JY 70 inductively coupled plasma atomic emission spectrometer. The analytical method is similar to the one described by Govindaraju and Mevelle (1987). Details about 
analytical procedures and uncertainties are available at http://www.crpg.cnrsnancy.fr/SARM/index.html.

Trace element concentrations for our samples (a gabbro from the intrusion, 7 sedimentary rocks and 7 metasedimentary rocks from the contact aureole) were measured by PQ2+ inductively coupled plasma mass spectrometer in the University of Grenoble, France. Due to the presence of refractory minerals, powders were dissolved in a $\mathrm{HF}^{-\mathrm{HNO}_{3}}$ (4:1) mixture in steeljacketed Teflon PARR bombs for 7 days at $150^{\circ} \mathrm{C}$. The analytical procedure for the ICP-MS measurements was described by Barrat et al. (1996) with modifications of Marini et al. (2005). The results are reported in Table 2 and plotted in Figure 5. The standard BR was used for calibration of the machine and reported concentrations are calculated relative to the BR composition given in Table 3. Values for other standards are reported in Table 3 and a duplicate analysis for EM64 is reported in Table 2.

\section{Petrology of the wall rocks}

\section{NeoProterozoic sedimentary rocks}

The sediment rocks at the lower contact with the intrusion belong to the Dengying Formation, which is up to $800 \mathrm{~m}$ thick in the Panzhihua area. Most of these rocks are massive, poorly bedded, beige to pale pink dolostones. Dedolomitization has resulted in the formation of rhomb-shaped crystals of calcite and rhomb-shaped areas composed of a mosaic of replacement calcite. Small veins of anhydrite indicate shallow-water deposition.

Most of the dolostones are almost pure and contain very low contents of clay or silica minerals but they interbedded with minor marlstone and shale layers. An exception is sample EM91, which contains $\sim 15$ vol\% of quartz and amorphous silica in its matrix. The marlstones and shale contain variable proportions of clay minerals and minor potassic feldspar. The dolostones and marls overlie clastic sedimentary rocks of the Doushantuo Formation including a quartz-rich arenite containing $88 \mathrm{wt} \% \mathrm{SiO}_{2}$. 


\section{Marble and skarn of the contact aureole}

Near the intrusion, within the contact aureole, the dolostones have been transformed into marbles, many of which contain brucite, diopside or forsterite and other silicate minerals (Table 4). Our reconnaissance mapping of the aureole, shown in the inset of Fig 3, indicates that it is more than $300 \mathrm{~m}$ thick. The most common rock type within the aureole is a homogenous, white, recrystallized marble that contains a very small amount of silicate minerals $(\sim 1 \%$, mainly olivine) but up to $40 \%$ brucite (Fig. 4e and sample EM39 in Tables 2 and 4). Grain size is uniform in the silica-poor skarns and ranges from $0.5 \mathrm{~mm}$ to $2 \mathrm{~mm}$.

Other metasedimentary rocks in the contact aureole contain a more diverse, siliceous metamorphic assemblage, suggesting either a shaley protolith or the introduction of silicon and other elements as aluminium, iron, titanium or potassium, during metamorphism. The proportion of silicate minerals is highly variable: some examples contain up to $40 \%$ of minerals such as olivine (now partially altered to serpentine), diopside, garnet, phlogopite and spinel. We identified phlogopite (up to 21\% in samples EM43b and EM47a), and wollastonite (EM47a) but the most abundant silicate mineral is diopside whose percentage in some cases exceeds that of calcite (EM44).

Most of the sedimentary rocks in the contact aureole are banded at a centimetre scale, the banding being defined by variations in grain size or in the proportions of silicate minerals. Plastic deformation of the rocks within the aureole has produced folding at different scales $(\mathrm{cm}$ to $\mathrm{m}$ ) and with different styles (Fig. 4a). The absence of deformation in rocks outside the aureole indicates that this deformation was directly related to the emplacement of the intrusion.

In our mapping we observed no systematic variations in the proportions and types of metamorphic minerals. The abundances and sizes of the carbonate and silicate minerals remained similar along a traverse to the base of the carbonate unit at a distance of $450 \mathrm{~m}$ from the base of the intrusion (Fig. 3). At a more local scale there were some variations in the mineralogy and texture. Some unusual skarns, referred to informally as zebra rocks, contain conspicuous stripes of white and black minerals organized with concentric symmetry around a small, $\sim 10 \mathrm{~cm}$ scale, 
nucleus of diopside-rich rock (Figs. $4 \mathrm{c}$ and $4 \mathrm{~d}$ ). The white stripes are mainly composed of calcite and dolomite and the dark stripes contain up to $80 \%$ of small $(0.2 \mathrm{~mm})$, euhedral grains of olivine (Fo90), now partially or completely altered to serpentine. The occurrence of spinel in the dark stripes is linked to the presence of about $5 \mathrm{wt} \% \mathrm{Al}_{2} \mathrm{O}_{3}$ in this rock. The minor oxide phases are ilmenite and magnetite. The form and geometry of the concentric banding strongly resembles that described in marbles intruded by dolerite dykes in Skye by Holness (1997) who attributes the formation of the structure to post-nucleation geochemical self-organization.

A totally different type of skarn occurs in a vein cutting across the contact between the intrusion and its wall rocks. This rock is coarse grained and contains clinozoisite, prehnite, hydrogrossular and small amount of sulfide (EM93 in Table 4). This kind of rock, which we interpret as a late vein that represents remobilised skarn material, was observed in only a single small outcrop at the contact between the wall rock and the intrusion in the lower unit.

\section{Whole-rock geochemistry}

\section{Sedimentary rocks}

The Doushantuo Formation, which forms the footwall of the Panzhihua intrusion, is composed primarily of very pure dolostones, as described in the section on petrology of the wall rocks and as reflected in their chemical compositions. Representative samples such as EM34 EM36, EM88 and EM89, contain $31 \mathrm{wt} \% \mathrm{CaO}$ and $21 \mathrm{wt} \% \mathrm{MgO}$ and $46 \mathrm{wt} \%$ loss-on-ignition $\left(=\mathrm{CO}_{2}\right)$, values very close to those of pure dolomite. Contents of $\mathrm{SiO}_{2}$ and $\mathrm{Al}_{2} \mathrm{O}_{3}$ are generally very low $(<0.5 \mathrm{wt} \%)$, indicating minimal amounts of silicate and clay minerals. An exception is the siliceous dolostone EM 91 which contains $20 \mathrm{wt} \% \mathrm{SiO}_{2}$.

Our single analysis of a marlstone (sample EM90) contains higher $\mathrm{SiO}_{2}$ and $\mathrm{Al}_{2} \mathrm{O}_{3}$ contents and lower loss-on-ignition $(\sim 14 \%)$ indicating a lower carbonate content and a moderate amount of potassium feldspar or clay minerals. The sample of quartz arenite from the underlying Dengying Formation (EM92) contains $88 \mathrm{wt} \% \mathrm{SiO}_{2}$, in accord with its high quartz content. 
Moderate $\mathrm{Al}_{2} \mathrm{O}_{3}(5.8 \mathrm{wt} \%)$ and $\mathrm{K}_{2} \mathrm{O}(2.6 \mathrm{wt} \%)$ contents indicate the presence of minor clay or detrital feldspar.

\section{Marble and skarn from the contact aureole}

The metasedimentary rocks of the contact aureole cover a large range of compositions, as illustrated in Figure 6. The contents of $\mathrm{SiO}_{2}$ vary widely, from 0.1 to 0.8 wt $\%$ in the brucite marbles to 44 wt\% in two epidote-rich skarns (e.g. EM47B and EM93). There are good positive correlations between $\mathrm{SiO}_{2} \mathrm{Al}_{2} \mathrm{O}_{3}$ and $\mathrm{Fe}_{2} \mathrm{O}_{3}$ and a negative correlation between $\mathrm{SiO}_{2}$ and loss-onignition. Most skarns plot between the compositions of unmetamorphosed dolostones and the single marlstone that we analyzed (EM90). One exception is the white marble EM108, whose composition is similar to that of the cherty dolostone EM91. Another is the three calc-silicate samples with unusually low loss-on-ignition values (EM43, 86 and 98). Sample EM43, a garnetrich calc-silicate, also has an unusually high $\mathrm{K}_{2} \mathrm{O}$ content $(4.6 \mathrm{wt} \%)$.

We interpret these relationships to indicate that the metamorphism in the contact aureole had relatively little effect on major-element compositions, except for the loss of $\mathrm{CO}_{2}$. Most of the variations can be explained by metamorphism of different types of protolith. The predominant brucite marbles are the products of metamorphism of pure dolostones, and the calcsilicate are the products of dolomite contained different amounts of clay and other detrital minerals, or, in the case of sample EM108, of cherty material. The nature of the protolith of the other samples is difficult to infer on the basis of major element compositions or metamorphic mineral assemblages, but the presence of garnet and high $\mathrm{Al}_{2} \mathrm{O}_{3}$ and $\mathrm{K}_{2} \mathrm{O}$ contents of sample EM43 suggests detrital potassium feldspar.

The compositions of the brucite marbles provide an indication of the amount of $\mathrm{CO}_{2}$ that was released during the contact metamorphism. Their loss-on-ignition is $\sim 38.9 \mathrm{wt} \%$, about $7 \%$ lower than that of the unmetamorphosed dolomite, but the $\mathrm{MgO} / \mathrm{CaO}$ ratio (0.66) is similar to that of the dolostones (0.69-0.71). These values are interpreted to indicate that the brucite, which 
constitutes about $40 \%$ of the sample, results from the reaction of dolomite to periclase and calcite, followed by hydration of the periclase to form brucite, via the reactions:

$$
\begin{aligned}
& \mathrm{CaMg}\left(\mathrm{CO}_{3}\right)_{2}(\text { dolomite })=\mathrm{CaCO}_{3}(\text { calcite })+\mathrm{MgO}(\text { periclase })+\mathrm{CO}_{2} \\
& \mathrm{MgO} \text { (periclase })+\mathrm{H}_{2} \mathrm{O}=\mathrm{Mg}(\mathrm{OH})_{2} \text { (brucite) }
\end{aligned}
$$

At very low partial pressures of $\mathrm{CO}_{2}$ and relatively high partial pressure of water, dolomite can break down directly to brucite and calcite at temperature above about $400^{\circ} \mathrm{C}$ (Turner 1965). No relicts of periclase have been found in the samples and we cannot be sure whether the destabilization of dolomite proceeded in two stages or whether it was the result of direct decarbonatization and hydration via the reaction:

$$
\left.\mathrm{CaMg}\left(\mathrm{CO}_{3}\right)_{2}(\text { dolomite })+\mathrm{H}_{2} \mathrm{O}=\mathrm{CaCO}_{3} \text { (calcite }\right)+\mathrm{Mg}(\mathrm{OH})_{2} \text { (brucite) }+\mathrm{CO}_{2}
$$

We note, however, that high partial pressures of water are unlikely within the portions of the contact aureole located entirely within carbonate lithologies of the aureole and we believe that the two-step process is the more probable.

\section{Trace elements}

Figure 5 shows the abundances of trace elements, normalized to primitive mantle (Hofmann 1988) of metasedimentary rocks from the contact aureole and their unmetamorphosed equivalents. The trace element compositions of the unmetamorphosed sedimentary rocks depend strongly on their lithology. The dolostones have very low concentrations of the rare earths and most other trace elements, typically around 0.1 times primitive mantle (Fig. 5a). Concentrations of $\mathrm{U}, \mathrm{Pb}$ and $\mathrm{Sr}$ are much higher and they define strong positive anomalies in mantle-normalized patterns; concentrations of $\mathrm{Nb}$ and $\mathrm{Ta}$ are relatively low and they define negative anomalies. The marlstones and quartz sandstone have much higher concentrations of trace elements, around 10 
times primitive mantle for the heavy REE and 100 times primitive mantle for the most incompatible elements. Both types of rock have small positive $\mathrm{Sr}$ anomalies and distinct negative $\mathrm{Nb}-\mathrm{Ta}$, Sr and Ti anomalies

The marbles and skarns in the contact aureole also show a large variation of trace-element patterns. In some, the trace element patterns are very similar to those of the sedimentary rocks: the composition of the meta-sandstone at the margin of the aureole (EM107) is almost identical to that of the unmetamorphosed sandstone (EM39, Fig. 5b) and the patterns of three marbles (EM65, 74 and 108) share with unmetamorphosed dolostones the positive $\mathrm{Pb}$ and $\mathrm{Sr}$ anomalies and low concentrations of most other trace elements.

One sample, EM39, analyzed in triplicate to verify the accuracy of its unusual pattern (Fig. 5c), has relatively high concentrations of the rare earths and large-ion lithophile elements such as $\mathrm{Rb}$ and $\mathrm{Ba}(0.5$ to 5 times primitive mantle), and enormous negative anomalies for most of the high-field strength elements (HFSE: Nb-Ta, Zr-Hf, Ti but not Y). In the other marbles and skarns the levels of all trace elements are generally between 1 and about 50 times primitive mantle. Most samples have inherited the positive $U$ anomalies of the unmetamorphosed dolostones, but levels of $\mathrm{Pb}, \mathrm{Sr}$ and $\mathrm{Ti}$ differ from one sample to another; some have small positive anomalies, as in the sedimentary rocks, others have negative anomalies.

The levels of trace elements such as the REE or, to a lesser extent, the HFSE correlate positively in most samples with major elements such as $\mathrm{SiO}_{2} \mathrm{Al}_{2} \mathrm{O}_{3}$ and $\mathrm{Fe}_{2} \mathrm{O}_{3}$. Of the three samples with dolostone-like trace element patterns, two are brucite marbles with major element compositions like those of unmetamorphosed dolostone but for lower loss-on-ignition (39 wt\% cf. $46 \mathrm{wt} \%$ ) and the third (EM108) is the siliceous marble interpreted as a metamorphosed cherty dolostone. Most of the other samples plot between the compositions of dolostones and the marlstone, supporting the interpretation that the metamorphism was largely isochemical (but for the loss of $\mathrm{CO}_{2}$ ) and that the compositions are controlled mainly by the clay or detrital mineral content of the protolith. The exception is sample EM39, the brucite marble with the large negative HFSE anomalies (EM39, Fig. 5c). This sample has a major element composition like 
the unmetamorphosed dolostone, but its contents of REE contents are distinctly higher. The fractionation of the trace element is illustrated by the variation of $\mathrm{La} / \mathrm{Zr}$ in these samples (Fig. 6c). As discussed by Ganino et al. (in preparation) the trace element contents of some samples were modified during the contact metamorphism.

\section{Discussion}

\section{Petrological interpretation of the Panzhihua Intrusion}

In this section we address the question of why so much Fe-Ti-oxide crystallized in the Panzhihua intrusion, both in the ore deposits and in the melanogabbros of the lower units. There are two end-member solutions: either the parental magma of the intrusion was rich in $\mathrm{Fe}$ and $\mathrm{Ti}$ and this led directly to the formation of cumulates with high titanomagnetite contents, or Fe-Tioxides were efficiently concentrated from magma with a more normal composition.

Pang et al. (2008b) used Zhou et al.'s (2005) calculation of the bulk composition of the intrusion as an estimate of the parental liquid composition. This composition contains high contents of $\mathrm{FeO}_{\text {(tot) }}$ and $\mathrm{TiO}_{2}$, and low $\mathrm{SiO}_{2}$ (Table 5) which Pang et al. (2008b) explained by involving fractionated crystallization at high pressure $(10 \mathrm{kbar})$ and they noted that such a magma would crystallize large quantities of Fe-Ti-oxides. A problem with this interpretation is the cumulus nature of the rocks in the Panzhihua intrusion. The ternary diagram $\mathrm{FeO}-\mathrm{MgO}-\mathrm{CaO}$, (Fig. 7) shows that the compositions of these rocks diverge away from the average composition of Emeishan basalts towards two major end-member compositions, one that corresponds to titanomagnetite and the other that corresponds to plagioclase. Figure 8a shows the accumulation trends of olivine and clinopyroxene observed for other Permian intrusions in Panxi region. Some of the rocks in Panzhihua intrusion contain a very high proportion of cumulus minerals, up to $75 \%$ Fe-Ti-oxide in the ores, and up to $55 \%$ for plagioclase in some anorthosites and variations in the proportion of these cumulus minerals explain most of the variation in major and trace element compositions within the intrusion. Most importantly, the bulk composition of the 
intrusion has higher $\mathrm{FeO}$ (tot) and $\mathrm{TiO}_{2}$, and lower $\mathrm{SiO}_{2}$, than the average composition of Emeishan basalts as seen in Figure 7.

In a more recent paper Pang et al. (2008a) observed that the mode, texture and mineral composition of the oxide inclusions in cumulus olivine provide direct evidence for early saturation of Fe-Ti oxide in Panzhihua magma. They argued on this basis that Fe-Ti oxides appeared on the liquidus at the same stage as olivine and clinopyroxene. In addition, they estimated the oxygen fugacity $\left(\mathrm{fO}_{2}\right)$ during crystallization using ilmenite-magnetite geothermometry. The oxides now preserved in the intrusion equilibrated at a subsolidus temperature of about $550^{\circ} \mathrm{C}$ but they extrapolated the temperature- $\mathrm{fO}_{2}$ relations along the isopleth to magmatic conditions, assuming that the oxides cooled in a closed system. On this basis they estimated that an $\mathrm{fO}_{2}$ above the fayalite-magnetite-quartz buffer $\left(\mathrm{fO}_{2}>\mathrm{FMQ}+1.5\right)$ at a magmatic temperature of $1000^{\circ} \mathrm{C}$. This condition is more oxidizing than that of most terrestrial basaltic magmas (Kress and Carmichael 1991).

Using the composition of an Emeishan basalt for the parental magma, and assuming a water content of $1.5 \mathrm{wt} \%$, Pang et al. (2008a) undertook additional MELTS modelling that showed that under these relatively oxidizing conditions, Fe-Ti oxides crystallized early in the crystallization sequence. They argued that crystallization under these conditions allowed the oxides to segregate efficiently from the host magma, and suggested that this behaviour provided an explanation for the large concentrations of Fe-Ti-oxides in the Panzhihua intrusion.

We agree with most of Pang et al.'s (2008a) arguments but question whether the parental magma would have had such a high $\mathrm{H}_{2} \mathrm{O}$ content. We acknowledge that the presence of amphibole and biotite provides evidence for the presence of some water (or halogens) in the magma, but suggest that these minerals could have crystallized at a late stage from interstitial liquid within which water had become concentrated. To constrain the water content of the parental magma, we employ the method used by Dixon et al (2002). These authors showed that in fresh, undegassed basalts from oceanic settings, the $\mathrm{H}_{2} \mathrm{O} / \mathrm{Ce}$ ratio varies from 100 to 200 . Ce concentrations can be used to estimate the $\mathrm{H}_{2} \mathrm{O}$ contents of modern oceanic basalts. The same 
approach can be employed for old altered rocks such as those from the Emeishan province. Using the Ce contents of Emeishan basalts measured by Song et al. (2001) (0.2 to $0.7 \mathrm{ppm}$ ) and $\mathrm{H}_{2} \mathrm{O} / \mathrm{Ce}$ ratios of 100 to 200 we estimate that the initial $\mathrm{H}_{2} \mathrm{O}$ contents of these magmas were low, between $0.2 \mathrm{wt} \%$ and $0.7 \mathrm{wt} \%$.

We then undertook petrological modelling using the composition of the Emeishan basalt listed in Table 5, assuming a water content at $0.5 \mathrm{wt} \%$. The pressure was set at $2 \mathrm{kbar}$, corresponding to intrusion at a crustal depth of about $5 \mathrm{~km}$ (We chose a relatively low pressure because of the excellent preservation of shallow-water textures in the dolostones which indicate that these rocks were never buried to significant depths). Under these conditions, the first solid phase to crystallize is olivine at the liquidus temperature of $1190^{\circ} \mathrm{C}$, followed closely by clinopyroxene and plagioclase at $1130^{\circ} \mathrm{C}$, after $5 \%$ of liquid has crystallized (Fig. 9). Magnetite appears only at $1055^{\circ} \mathrm{C}$, when $50 \%$ of the melt has crystallized and then crystallizes rapidly, over a very small temperature interval $(70 \%$ of the total magnetite crystallizes in a temperature interval of $25^{\circ} \mathrm{C}$ ). The last phases to crystallize are hematite-ilmenite, apatite, biotite and $\mathrm{K}$ feldspar. Figure 8 shows the evolution of the composition of the liquid phase.

This sequence of crystallization corresponds in many respects to the sequence inferred for the Panzhihua intrusion. Notable is the small interval, $\sim 10 \%$ between the liquidus and the appearance of plagioclase, which is consistent with the presence of this mineral as a cumulus phase in the lowermost layers of the intrusion. In contrast, the large interval, $40 \%$, between the liquidus and the appearance of magnetite is inconsistent with the presence of abundant Fe-Tioxides in the lower part of the intrusion. In other words, during the crystallization of an $\mathrm{H}_{2} \mathrm{O}$ poor magma with the composition of an Emeishan basalt, Fe-Ti-oxides only appear late in the sequence. To explain the high abundance of these minerals in the lower cumulates and the ore deposits requires that conditions during crystallization were different from those in our initial model. In the following section we develop a model in which the oxygen fugacity during crystallization was increased through interaction with $\mathrm{CO}_{2}$ released during decarbonatization of 
the sedimentary rocks in the contact aureole, and that this change led to the early crystallization of the Fe-Ti-oxides.

\section{Degassing of the contact aureole and oxygen fugacity in the Panzhihua magma}

As discussed above, metamorphism of the rocks in the contact aureole appears to have been largely isochemical, but for minor redistribution of the rare earth elements and considerable loss of $\mathrm{CO}_{2}$. A simple calculation based on reactions (1) to (3) indicates that each kilogram of dolostone would have released 239 grams of $\mathrm{CO}_{2}$ if the sedimentary rock were transformed completely into brucite marble. This amount of $\mathrm{CO}_{2}$ loss can be verified using the difference between the loss-on-ignition of unmetamorphosed dolostone ( $46 \mathrm{wt} \%)$ and the brucite marble representative the contact aureole $(\sim 39 \mathrm{wt} \%)$. The total loss of $\mathrm{CO}_{2}$, calculated after correction for the weight gain associated with the hydration of periclase to brucite, corresponds closely with that predicted for complete transformation of dolomite to brucite plus calcite. The periclaseforming reaction proceeds only at a high temperature, around $700^{\circ} \mathrm{C}$, which would only be reached in the interior of the aureole. If the fluids within the aureole contained a significant water content, however, brucite could be produced at lower temperatures through reaction (3). And in impure limestones containing $\mathrm{SiO}_{2}$ or clay minerals, a variety of silicate minerals form at the expense of dolomite or calcite, each involving the release of $\mathrm{CO}_{2}$. Complete documentation of all these reactions is beyond the scope of this paper and they will be discussed in a forthcoming article (Ganino et al., in preparation).

We can make some conservative estimates of the dimensions of the part of the aureole that underwent partial decarbonatization. We assume that length of the aureole was that of the intrusion, or $19 \mathrm{~km}$, the breadth was $2 \mathrm{~km}$ and the thickness was $300 \mathrm{~m}$, giving a total volume of $11.4 \mathrm{~km}^{3}$. If the rock density is $2750 \mathrm{~kg} \mathrm{~m}^{-3}$, the mass of dolostone was $31.4 \mathrm{Gt}$. If we assume that $80 \%$ of dolomite is transformed into brucite, then $190 \mathrm{~g}$ of $\mathrm{CO}_{2}$ is released for each kilogram of rock. The total amount of $\mathrm{CO}_{2}$ is then calculated as $6.0 \mathrm{Gt}$. The possible impact on global climate of expulsion of $\mathrm{CO}_{2}$ from the entire Emeishan igneous province is discussed by Ganino et al. (in preparation). 
We do not know exactly what happened to the $\mathrm{CO}_{2}$ released from the aureole beneath the Panzhihua intrusion. Part of it could initially have been trapped beneath the intrusion, but since the magmatic rocks at the contact are remarkably fresh and show no sign of carbonatization, it appears that rather than interacting with the rocks as they cooled, most of the $\mathrm{CO}_{2}$ escaped to the surface. Some of it may have flowed along to base until it reached fractures or the end of the intrusion, but carbonated shear-zones and other structures marking focussed flow of $\mathrm{CO}_{2}$-rich fluid have not been mapped and are not exposed in the open pit. We assume, therefore, that at least part of the $\mathrm{CO}_{2}$ passed up through the intrusion itself. Since the solubility of $\mathrm{CO}_{2}$ is minimal in silicate melt at low pressure, the $\mathrm{CO}_{2}$ would not have dissolved in the magma, but it would have interacted with it.

According to Wenzel et al. (2002), decomposition of carbonate xenoliths and wall rocks in the Ioko-Dovyren mafic-ultramafic intrusion in Russia created highly oxidizing $\mathrm{CO}_{2}$-rich fluids that reacted with the magma and influenced the sequence of crystallization. In the following section we investigate the possibility that interaction between $\mathrm{CO}_{2}$-rich fluids and magma had a comparable effect on the Panzhihua magma and that this interaction led to the early crystallization of Fe-Ti-oxides.

\section{Interaction of $\mathrm{CO}_{2}$-rich fluids with the magma}

To investigate the crystallization of the Panzhihua intrusion, we modelled how a $\mathrm{CO}_{2}-$ rich fluid released by dolomite decomposition would affect the equilibrium $\mathrm{fO}_{2}$ as it bubbled up through, and interacted with, magma in the overlying intrusion The calculation consists in computing redox equilibria between silicate liquid and a gas phase whose composition is defined by equilibria such as $\mathrm{CO}_{2}-\mathrm{CO}, \mathrm{H}_{2} \mathrm{O}-\mathrm{H}_{2} \mathrm{~S}_{2}-\mathrm{H}_{2} \mathrm{~S}-\mathrm{SO}_{2}$. To determine the redox state of the magma, we performed combined thermodynamic and mass balance calculations following a procedure similar to that of Scaillet and Pichavant (2005). Equilibrium constants for reactions in the gas phase were taken from Holloway (1987) and the oxygen fugacity in the basaltic melt is computed after Kress and Carmichael (1991). Gas-melt equilibria integrating relevant solubility laws for water and $\mathrm{CO}_{2}$ (Newman and Lowenstern 2002) and sulfur (O'Neill and Mavrogenes 
2002) were computed together with the equations of speciation in the gas from Scaillet and Pichavant (2005).

We assumed that the mafic magma contained $8 \mathrm{wt} \% \mathrm{FeO}$ at $1300^{\circ} \mathrm{C}$ at a pressure of 200 $\mathrm{MPa}$. The results shown in Figure 10a illustrate the effect of adding $\mathrm{CO}_{2}$ to a mafic magma that had initially equilibrated at $\mathrm{fO}_{2}$ close to the fayalite-magnetite-quartz (FMQ) buffer. We fixed the initial water content at $0.3 \mathrm{wt} \%$, the sulfur content at $1000 \mathrm{ppm}$ and $\mathrm{CO}_{2}$ content at $\sim 700 \mathrm{ppm}$, values that correspond to volatile saturation in the COHS system at $200 \mathrm{MPa}$. Any $\mathrm{CO}_{2}$ added to such a system triggers the formation of a fluid phase and requires a redistribution of $\mathrm{C}, \mathrm{H}, \mathrm{O}, \mathrm{S}$ species between melt and gas. The overall oxidative action of $\mathrm{CO}_{2}$ can be simplified as $\mathrm{CO}_{2}+2$ $\mathrm{FeO}=\mathrm{CO}+\mathrm{Fe}_{2} \mathrm{O}_{3}$. The interaction thereby affects the $\mathrm{Fe}^{3+} / \mathrm{Fe}^{2+}$ equilibrium in the melt and changes the $\mathrm{fO}_{2}$. We checked that the choice of the initial compositions (i.e. volatile abundances) does not significantly modify the calculation. Given that we simulated the effect of adding several $\mathrm{wt} \%$ of $\mathrm{CO}_{2}$ and that $0.2 \mathrm{wt} \% \mathrm{CO}_{2}$ is enough to trigger the formation of a fluid phase, we are confident that the choice of the initial composition of the system remains a second order parameter.

Figure 10a shows that the addition of $10 \mathrm{wt} \%$ of $\mathrm{CO}_{2}$ to the basalt increases oxygen fugacity by about one order of magnitude. It is difficult to judge whether such a high proportion of $\mathrm{CO}_{2}$ is reasonable. A simple calculation based on the mass of $\mathrm{CO}_{2}$ released from the aureole by the brucite-forming reaction and the mass of the intrusion based on its exposed dimensions gives a $\mathrm{CO}_{2} /$ magma mass ratio of about $1 \%$. This ratio is only a first approximation, however. It would be decreased if we take into account the probability that the intrusion behaved as an open system and the likelihood that not all the released $\mathrm{CO}_{2}$ interacted with the magma. But it would be increased, perhaps substantially, if the sum of all $\mathrm{CO}_{2}$-forming reactions, including those involving silicates, and additional $\mathrm{CO}_{2}$ released through total assimilation of the carbonates, were taken into account. A final factor is interaction with carbonates deeper in the magma system. We can conclude that the total amount of added $\mathrm{CO}_{2}$ was several percent, enough to significantly increase the $\mathrm{fO}_{2}$. 
In Figure 10a, the initial small $\mathrm{fO}_{2}$ decrease is due to the formation of a $\mathrm{CO}_{2}$-rich fluid phase in the magma, which decreases the water fugacity. The injection of larger amount of $\mathrm{CO}_{2}$ into the system increases the $\mathrm{CO}_{2} / \mathrm{CO}$ ratio and this triggers a major increase in $\mathrm{fO}_{2}$. Due to the low $\mathrm{CO}_{2}$ solubility in the melt, all added $\mathrm{CO}_{2}$ is incorporated in the fluid phase (Iacono Marziano et al. 2007) which immediately leads to extremely high gas content in the system. Such high gas content in the magma is not gravitationally stable (Menand and Phillips 2007) and at relatively short timescales, the gas segregates and is expelled from the magma generating active hydrothermal systems at shallower depth (Iacono Marziano et al. 2007). We therefore modified our calculation considering batch extraction of the gas after the proportion of fluid phase reached $1 \mathrm{wt} \%$ (4-7 vol. \%). $\mathrm{CO}_{2}$ fluxing through the melt causes much greater oxidation because the reduced species $\left(\mathrm{H}_{2}\right.$ and $\left.\mathrm{CO}\right)$ are less insoluble in the melt than their oxidized forms $\left(\mathrm{H}_{2} \mathrm{O}\right.$ and $\mathrm{CO}_{2}$ ) and are therefore concentrated in the gas. Batch extraction of the gas therefore leads to a major enhancement of the oxidative capacity of $\mathrm{CO}_{2}$ fluxing, as shown in Figure 10a. We predict a major increase of $1.5 \log$ unit in $\mathrm{fO}_{2}$, which corresponds to the estimation of oxygen fugacity made by Pang et al. (2008b), and which is sufficient to bring magnetite close to the liquidus (Fig. 10b) as shown by Toplis and Carroll (1995).

For a chemical composition close to that of the Emeishan basalts, the final amount of magnetite predicted by PELE modelling (Boudreau 1999) is about 6-8\%. If this mineral could efficiently segregate during the crystallization, there is quite enough to form the ore bodies, whose mass is only about $1 \%$ of that of the intrusion itself. When the oxygen fugacity is around FMQ, as is normally assumed for tholeiitic magmas, the oxides crystallize late and are unlikely to accumulate efficiently to form the ore deposits. However, if the $\mathrm{fO}_{2}$ is boosted by interaction with $\mathrm{CO}_{2}$-rich fluids, as described above, then the oxides will crystallize close to the liquidus and will segregate more easily. We propose, therefore, that the release of $\mathrm{CO}_{2}$ during metamorphism of the carbonate floor rocks was instrumental in the ore-forming process. 


\section{Conclusions}

(1) The Panzhihua gabbroic intrusion consists largely of plagioclase, olivine, pyroxene and magnetite cumulates whose compositions can be explained by the crystallization of magma with a composition like that of a relatively evolved Emeishan basalt.

(2) The contact aureole provided the oxidizing conditions in the magma by releasing $\mathrm{CO}_{2}$ rich fluids. The heating of dolostones produced low- $\mathrm{SiO}_{2}$ brucite skarns and was responsible of a large part of the degassing.

(3) Modelling of redox equilibria in the system Fe, C, O, H, S shows that interaction with $\mathrm{CO}_{2}$-rich fluids increases the oxygen fugacity of the magma.

(4) Oxidizing conditions result in the early crystallization of magnetite. When magnetite crystallizes in the earliest stages, it can segregate in the liquid because of its high density. Density segregation of early-crystallized magnetite could be an explanation of ore deposits at the bottom of the gabbroic body.

\footnotetext{
Acknowledgements We express our gratitude to Fernando Tornos, Chris Harris, and Michael Toplis for their constructive comments and their help with the preparation of the manuscript. We thank J. Gregory Shellnutt for interesting and useful discussions, Professor Yuxiao Ma for providing assistance during our fieldwork and Adeline Besnault for her assistance with the geochemical analyses. Constructive and helpful reviews were provided by Bernd Lehmann, Peter Lightfoot, Steve Prevec and an anonymous reviewer. The project was initiated during a PROCORE exchange program between France and Hong Kong Research Grants Council. Financial support for the research was obtained from the French CNRS (DyETI program).
} 


\section{References}

Barrat JA, Keller F, Amossé J, Taylor RN, Nesbitt RW, Hirata T (1996) Determination of rare earth elements in sixteen silicate reference samples by ICP-MS after Tm addition and ion exchange separation. Geostandards Newsletter 20: 133-139.

Boudreau AE (1999) PELE - a version of the MELTS software program for the PC platform. Computers \& Geosciences 25: 201-203.

Burchfiel BC, Chen Z, Liu Y, Royden LH (1995) Tectonics of the Longmen Shan and adjacent regions, central China. International Geology Review 37: 661-735.

Chung S-L, Jahn B-M (1995) Plume-lithosphere interaction in generation of the Emeishan flood basalts at the Permian-Triassic boundary. Geology 23: 889-892.

Chung SL, Jahn BM, Wu GY, Lo CH, Cong BL (1998) The Emeishan flood basalt in SW China: A mantle plume initiation model and its connection with continental break-up and mass extinction at the Permian-Triassic boundary. Mantle dynamics and plate interaction in East Asia: American Geophysical Union Geodynamic Series 27: 47-58.

Courtillot V, Jaupart C, Manighetti I, Tapponnier P, Besse J (1999) On causal links between flood basalts and continental breakup. Earth and Planetary Science Letters 166: 177-195.

Dia A, Chauvel C, Bulourde M, Gérard M (2006) Eolian contribution to soils on Mount Cameroon: Isotopic and trace element records. Chemical Geology 226: 232-252.

Dixon JE, Leist L, Langmuir C, Schilling JG (2002) Recycled dehydrated lithosphere observed in plume-influenced mid-ocean-ridge basalt. Nature 420: 385-389.

Eggins SM, Woodhead JD, Kinsley LPJ, Mortimer GE, Sylvester P, McCulloch MT, Hergt JM, Handler MR (1997) A simple method for the precise determination of $=<40$ trace elements in geological samples by ICPMS using enriched isotope internal standardisation. Chemical Geology 134: 311-326.

Govindaraju K, Mevelle G (1987) Fully automated dissolution and separation methods for inductively coupled plasma atomic emission spectrometry rock analysis. Application to the determination of rare earth elements. Plenary lecture. Journal of Analytical Atomic Spectrometry 2: 615-621.

Hofmann AW (1988) Chemical differentiation of the Earth -The relationship between mantle, continental crust, and oceanic crust. Earth and Planetary Science Letters 90: 297-314.

Holloway JR (1987) Igneous fluids. Reviews in Mineralogy and Geochemistry 17: 211-233.

Holness MB (1997) Geochemical self-organization of olivine-grade contact metamorphosed chert nodules in dolomite marble, Kilchrist, Skye. Journal of Metamorphic Geology 15: 765-775.

Iacono Marziano G, Gaillard F, Pichavant M (2007) Limestone assimilation and the origin of $\mathrm{CO}_{2}$ emissions at the Alban Hills (Central Italy): Constraints from experimental petrology. Journal of Volcanology and Geothermal Research 166: 91-105.

Kress VC, Carmichael ISE (1991) The compressibility of silicate liquids containing $\mathrm{Fe}_{2} \mathrm{O}_{3}$ and the effect of composition, temperature, oxygen fugacity and pressure on their redox states. Contributions to Mineralogy and Petrology 108: 82-92.

Liu HY (1991) Sinian strata in China (in Chinese). Science Press, Beijing, 388 pp.

Lu J, Zhang G, Zhang C, Gu G (1988) Magma type and genesis of the basic-ultrabasic layered intrusions in Panzhihua-Xichang area, Southwest China. Chinese Journal of Geochemistry 7: 1-18.

Ma YX, Ji XT, Li JC, Huang M, Min ZZ (2003) Mineral resources of Panzhihua, Sichuan Province, SW China. Chengdu University of Technology, Chengdu, 275 pp.

Marini JC, Chauvel C, Maury RC (2005) Hf isotope compositions of northern Luzon arc lavas suggest involvement of pelagic sediments in their source. Contributions to Mineralogy and Petrology 149: 216-232.

Menand T, Phillips JC (2007) Gas segregation in dykes and sills. Journal of Volcanology and Geothermal Research 159: 393-408.

Newman S, Lowenstern JB (2002) VolatileCalc: a silicate melt- $\mathrm{H}_{2} \mathrm{O}-\mathrm{CO}_{2}$ solution model written in Visual Basic for excel. Computers and Geosciences 28: 597-604.

O'Neill H, Mavrogenes JA (2002) The Sulfide Capacity and the Sulfur Content at Sulfide Saturation of Silicate Melts at $1400^{\circ} \mathrm{C}$ and 1 bar. Journal of Petrology 43: 1049-1087. 
Pang KN, Li C, Zhou MF, Ripley EM (2008a) Abundant Fe-Ti oxide inclusions in olivine from the Panzhihua and Hongge layered intrusions, SW China: evidence for early saturation of Fe-Ti oxides in ferrobasaltic magma. Contrib Mineral Petrol DOI 10.1007/s00410-008-0287-z.

Pang KN, Zhou MF, Lindsley D, Zhao D, Malpas J (2008b) Origin of Fe Ti Oxide Ores in Mafic Intrusions: Evidence from the Panzhihua Intrusion, SW China. Journal of Petrology 49: 295-313.

Scaillet B, Pichavant M (2005) A model of sulfur solubility for hydrous mafic melts: application to the determination of magmatic fluid compositions of Italian volcanoes. Annals of Geophysics 48: 671-698.

Shellnutt JG, Zhou MF (2007) Permian peralkaline, peraluminous and metaluminous A-type granites in the Panxi district, SW China: Their relationship to the Emeishan mantle plume. Chemical Geology 243: 286-316.

Song X-Y, Zhou M-F, Hou Z-Q, Cao Z-M, Wang Y-L, Li Y (2001) Geochemical Constraints on the Mantle Source of the Upper Permian Emeishan Continental Flood Basalts, Southwestern China. International Geology Review 43: 213-225.

Song XY, Zhou MF, Cao ZM, Robinson PT (2004) Late Permian rifting of the South China Craton caused by the Emeishan mantle plume? 161: 773-781.

Tang HS (1984) The Panzhihua V-Ti-magnetite deposits (in Chinese). Geological Team of Sichuan Geological Survey (eds) Research Report

Tien CP (2000) The Permian of Vietnam, Laos and Cambodia and its interregional correlation. In: H. Yin, J.M. Dickins, G.R. Shi and J. Tong, Editors, Permo-Triassic Evolution of Tethys and Western Circum-Pacific. Elsevier, pp. 99-109.

Toplis MJ, Carroll MR (1995) An Experimental Study of the Influence of Oxygen Fugacity on Fe-Ti Oxide Stability, Phase Relations, and Mineral-Melt Equilibria in Ferro-Basaltic Systems. Journal of Petrology 36: 1137-1170.

Turner FJ (1965) Note on the genesis of brucite in contact metamorphism of dolomite. Contributions to Mineralogy and Petrology 11: 393-397.

Wenzel T, Baumgartner LP, Brugmann GE, Konnikov EG, Kislov EV (2002) Partial Melting and Assimilation of Dolomitic Xenoliths by Mafic Magma: the Ioko-Dovyren Intrusion (North Baikal Region, Russia). Journal of Petrology 43: 2049-2074.

Wignall PB (2001) Large igneous provinces and mass extinctions. Earth-Science Reviews 53: 1-33.

Xu Y, Chung S-L, Jahn B-M, Wu G (2001) Petrologic and geochemical constraints on the petrogenesis of PermianTriassic Emeishan flood basalts in southwestern China. Lithos 58: 145-168.

Zhou M-F, Malpas J, Song X-Y, Robinson PT, Sun M, Kennedy AK, Lesher CM, Keays RR (2002a) A temporal link between the Emeishan large igneous province (SW China) and the end-Guadalupian mass extinction. Earth and Planetary Science Letters 196: 113-122.

Zhou MF, Robinson PT, Lesher CM, Keays RR, Zhang CJ, Malpas J (2005) Geochemistry, Petrogenesis and Metallogenesis of the Panzhihua Gabbroic Layered Intrusion and Associated Fe-Ti-V Oxide Deposits, Sichuan Province, SW China. Journal of Petrology 46: 2253-2280.

Zhou MF, Yan DP, Kennedy AK, Li YQ, Ding J (2002b) SHRIMP zircon geochronological and geochemical evidence for Neoproterozoic arc-related magmatism along the western margin of Yangtze Block, South China. Earth and Planetary Science Letters 196: 51-67.

Zhou M-F, Arndt NT, Malpas J, Wang CY, Kennedy AK (2008) Two magma series and associated ore deposit types in the Permian Emeishan large igneous province, SW China. Lithos doi:10.1016/j.lithos.2007.10.006 


\section{Figure legends}

Fig. 1. Simplified regional geological map modified from Zhou et al. (2005), showing the distribution of the Emeishan flood basalts in SW China. The sketch map of China at the top right shows the location of the study area.

Fig. 2. (a) List of Proterozoic formations and their lithologies. add period (b) NW-SE cross-section modified from the geological map (1/50000). The position of the section is shown in Fig. 3. Quaternary formations are not shown. (c) Idealized stratigraphic section of the Panzhihua intrusion and the underlying sedimentary rocks (modified from Zhou et al. 2005).

Fig. 3. Geological map of the Panzhihua intrusion, modified from Tang (1984) and Zhou et al. (2005).

Fig. 4. Representative samples of rocks from the Panzhihua contact aureole : (a) Brucite marble with banding showing small-scale folding ( 1m) (b) Metamorphosed dolostone from the contact aureole in the Panzhihua open pit. "Zebra-rocks", concentric alternating light- and dark-coloured bands have developed around rounded blocks of altered detrital sedimentary rock. The white bands are composed of dolomite and calcite and the dark bands are composed mainly of serpentinized olivine. (c) Hand sample, and (d) photomicrograph of "zebra rock". The latter, taken under plane-polarized light shows partially altered olivine and oxide alternating with calcite. (e)

Photomicrograph (plane-polarized light) of brucite marble. (f) Photomicrograph of olivine marble (crossed polars). ol = olivine $;$ cal $=$ calcite $;$ brc $=$ brucite

Fig. 5. Mantle-normalized trace element diagram of sedimentary rocks and metasedimentary rocks from the contact aureole of Panzhihua gabbroic intrusion. Primitive mantle normalization values are from Hofmann (1988).

Fig. 6. Major and trace element variation diagrams showing the compositions of samples from rocks from the contact aureole adjacent to the Panzhihua intrusion and unmetamorphosed sedimentary rocks from Panzhihua region. In most diagrams, samples from the contact aureole lie close to the mixing line between marlstone and dolostones.

Fig. 7. Ternary diagrams showing the compositions of rocks from the Panzhihua intrusion. Olivine composition were measured at Hong Kong University and provided by K.N. Pang

Fig. 8. $\mathrm{Al}_{2} \mathrm{O}_{3}$ (wt $\%$ ), $\mathrm{TiO}_{2}$ (wt $\%$ ) and loss-on-ignition (LOI) (wt \%), $\mathrm{La}(\mathrm{ppm})$, and $\mathrm{La} / \mathrm{Zr} \mathrm{vs} \mathrm{SiO}_{2}$ (wt $\%$ ), and $\mathrm{La}$ (ppm) vs LOI (wt\%) for samples of sedimentary rocks far from the Panzhihua intrusion and rocks from Panzhihua contact aureole.

Fig. 9. Numerical modeling: crystallization of a melt with the composition of an Emeishan basalts (YL-2E in Table 5) using the PELE program from Boudreau (1999). $\mathrm{H}_{2} \mathrm{O}$ content $=0.5 \mathrm{wt} \%$; oxygen buffer $=$ Fayalite-MagnetiteQuartz .

Fig. 10. (a) Diagram illustrating the effect on the oxygen fugacity, expressed as $\triangle F M Q$, of interaction between a $\mathrm{CO}_{2}$-rich fluid and basaltic magma. Results from redox equilibrium computation in the system Fe, C, O, H, S. (b) Experimentally determined phase equilibria as a function of oxygen fugacity (modified from Toplis and Carroll (1995)). 
Table 1 Oxide compositions of the minerals of a skarn and a gabbro.

\begin{tabular}{|c|c|c|c|c|c|c|c|c|c|}
\hline \multirow[b]{2}{*}{$\begin{array}{l}\text { Rock name } \\
\text { mineral }\end{array}$} & \multicolumn{3}{|c|}{ Skarn } & \multicolumn{6}{|c|}{ Gabbro } \\
\hline & $\begin{array}{l}\text { EM64 } \\
\text { olivine }\end{array}$ & $\begin{array}{l}\text { EM64 } \\
\text { spinel }\end{array}$ & $\begin{array}{c}\text { EM64 } \\
\text { ilmenite } \\
\end{array}$ & $\begin{array}{c}\text { EM51 } \\
\text { cpx }\end{array}$ & $\begin{array}{c}\text { EM51 } \\
\text { pl }\end{array}$ & $\begin{array}{c}\text { EM51 } \\
\text { mt }\end{array}$ & $\begin{array}{c}\text { EM51 } \\
\text { ilm }\end{array}$ & $\begin{array}{c}\text { EM51 } \\
\text { hb }\end{array}$ & $\begin{array}{c}\text { EM51 } \\
\text { sp }\end{array}$ \\
\hline $\mathrm{SiO}_{2}$ & 41.5 & 0.0 & 0.0 & 50.4 & 52.6 & 0.0 & 0.0 & 40.3 & 0.0 \\
\hline $\mathrm{TiO}_{2}$ & 0.0 & 0.4 & 57.9 & 1.4 & & 18.7 & 17.5 & 6.0 & 0.2 \\
\hline $\mathrm{Al}_{2} \mathrm{O}_{3}$ & 0.0 & 65.1 & 0.0 & 4.0 & 29.8 & 6.6 & 2.5 & 13.6 & 64.1 \\
\hline $\mathrm{FeO}$ (tot) & 7.0 & 12.4 & 27.4 & 7.6 & 0.2 & 65.9 & 71.5 & 8.8 & 18.6 \\
\hline MnO & 0.1 & 0.1 & 0.4 & 0.2 & & 0.5 & 0.4 & 0.1 & 0.1 \\
\hline $\mathrm{MgO}$ & 51.3 & 21.2 & 13.9 & 14.2 & & 4.9 & 0.1 & 13.2 & 16.5 \\
\hline $\mathrm{CaO}$ & 0.0 & 0.1 & 0.0 & 20.7 & 12.6 & 0.0 & 0.1 & 12.1 & 0.0 \\
\hline $\begin{array}{c}\mathrm{Na}_{2} \mathrm{O} \\
\mathrm{K}_{2} \mathrm{O}\end{array}$ & 0.0 & 0.0 & 0.0 & 0.7 & $\begin{array}{l}4.4 \\
0.1\end{array}$ & 0.2 & 0.1 & 3.3 & 0.0 \\
\hline $\mathrm{Cr}_{2} \mathrm{O}_{3}$ & 0.0 & 0.8 & 0.1 & 0.0 & & 0.2 & 0.1 & 0.0 & 0.1 \\
\hline total & 99.9 & $\bar{~} 100.1$ & 99.9 & 99.3 & 99.7 & 97.0 & 92.4 & 97.3 & 99.6 \\
\hline
\end{tabular}




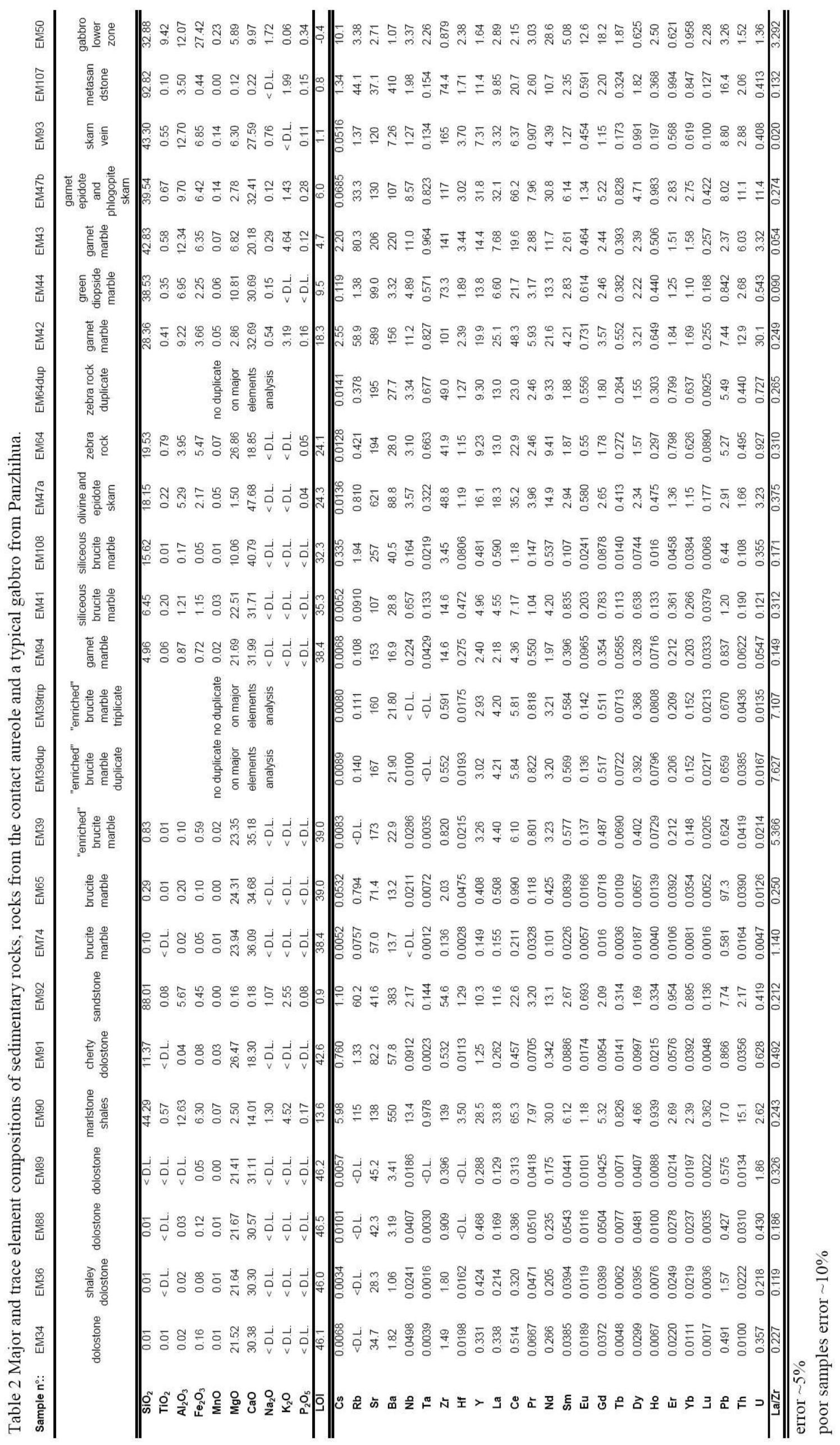


Table 3 Trace element composition of the standards used at LGCA Grenoble (France).

\begin{tabular}{|c|c|c|c|c|c|c|c|c|c|}
\hline & $\mathrm{BR}^{*}$ & $\underset{2^{\star \star}}{\text { BHVO- }}$ & $\begin{array}{l}\text { BHVO- } \\
2(n=6)\end{array}$ & $\underset{1^{* *}}{\text { AGV- }}$ & $\begin{array}{c}\text { AGV-1 } \\
(n=6)\end{array}$ & $\begin{array}{c}\text { BR } \\
24^{\star \star \star}\end{array}$ & $\begin{array}{c}\text { BR 24 } \\
(n=6)\end{array}$ & $B E N^{\star \star \star *}$ & $\begin{array}{l}\text { BEN } \\
(n=4)\end{array}$ \\
\hline Rb & "48.7 & 9.11 & 9.60 & " & $\begin{array}{l}71.6 \\
\end{array}$ & $\overline{c 79.3}$ & 85.8 & " 49.6 & $\begin{array}{l}49.8 \\
\end{array}$ \\
\hline $\mathrm{Sr}$ & 1364 & 396 & 410 & 660 & 697 & 617 & 637 & 1420 & 1416 \\
\hline$Y$ & 31.5 & 26 & 29.2 & 19 & 21.9 & 31.0 & 31.8 & 29.6 & 32.0 \\
\hline $\mathrm{Zr}$ & 283 & 172 & 186 & 231 & 251 & 314.6 & 311 & 273 & 286 \\
\hline $\mathrm{Nb}$ & 119.3 & 18.1 & 19.4 & 14.6 & 15 & 41.81 & 39.9 & 101 & 121 \\
\hline Cs & 0.823 & 0.1 & 0.10 & 1.26 & 1.31 & 0.754 & 0.644 & 0.741 & 0.764 \\
\hline $\mathrm{Ba}$ & 1082 & 131 & 129 & 1200 & 1223 & 393 & 382 & 1056 & 1042 \\
\hline La & 82.1 & 15.2 & 14.9 & 38.2 & 37.9 & 34.7 & 33.2 & 82.7 & 82.1 \\
\hline $\mathrm{Ce}$ & 152.2 & 37.5 & 37.0 & 67.6 & 70.0 & 74.4 & 73.5 & 154 & 153 \\
\hline $\mathrm{Pr}$ & 17.36 & 5.35 & 5.31 & 8.3 & 8.50 & 9.99 & 9.53 & 17.3 & 17.3 \\
\hline $\mathrm{Nd}$ & 66.1 & 24.5 & 24.3 & 31.7 & 32.1 & 41.1 & 39.3 & 67.1 & 66.2 \\
\hline $\mathrm{Sm}$ & 12.11 & 6.07 & 6.11 & 5.72 & 5.82 & 8.68 & 8.36 & 12.4 & 12.2 \\
\hline $\mathrm{Eu}$ & 3.58 & 2.07 & 2.00 & 1.58 & 1.59 & 2.60 & 2.46 & 3.91 & 3.60 \\
\hline Gd & 9.57 & 6.24 & 5.98 & 4.7 & 4.67 & 7.83 & 7.27 & 10.4 & 9.59 \\
\hline $\mathrm{Tb}$ & 1.29 & 0.92 & 0.92 & 0.69 & 0.663 & 1.10 & 1.05 & 1.35 & 1.29 \\
\hline Dy & 6.3 & 5.31 & 5.20 & 3.55 & 3.51 & 5.87 & 5.67 & 6.53 & 6.27 \\
\hline Ho & 1.087 & 0.98 & 0.99 & 0.68 & 0.692 & 1.09 & 1.05 & 1.08 & 1.08 \\
\hline $\mathrm{Er}$ & 2.59 & 2.54 & 2.56 & 1.82 & 1.89 & 2.79 & 2.73 & 2.71 & 2.58 \\
\hline $\mathrm{Yb}$ & 1.806 & 2 & 1.98 & 1.63 & 1.64 & 2.15 & 2.10 & 1.77 & 1.80 \\
\hline Lu & 0.251 & 0.274 & 0.282 & 0.244 & 0.253 & 0.306 & 0.306 & 0.25 & 0.251 \\
\hline $\mathrm{Hf}$ & 5.62 & 4.36 & 4.37 & 5.1 & 5.09 & 6.98 & 6.71 & 5.71 & 5.62 \\
\hline $\mathrm{Ta}$ & 5.79 & 1.14 & 1.19 & 0.87 & 0.864 & 2.51 & 2.40 & 6.03 & 5.77 \\
\hline $\mathrm{Pb}$ & 4.77 & 1.6 & 2.39 & 37.4 & 37.7 & 3.62 & 3.70 & 3.97 & 3.97 \\
\hline Th & 10.87 & 1.22 & 1.25 & 6.4 & 6.49 & 4.81 & 4.85 & 10.9 & 10.9 \\
\hline $\mathrm{U}$ & 2.46 & 0.403 & 0.411 & 1.93 & 1.90 & 1.19 & 1.23 & 2.46 & 2.45 \\
\hline
\end{tabular}

The standard BR was used for calibration of the machine. Our measurements of two international standards (BHVO2 and $\mathrm{AGV}-1)$ and two in-house standard (BR24 and BEN) are compared to the reference values from *(Eggins et al. 1997), **GEOREM : http://georem.mpch-mainz.gwdg.de , ***(Marini et al. 2005), ****(Dia et al. 2006). 
Table 4 Mineral compositions, grain size, texture and distribution of different skarns from the contact aureole in Panzhihua.

\begin{tabular}{cccccccccc} 
Sample n:: & EM65 & EM39 & EM43a & EM43b & EM44 & EM47a & EM47b & EM64 & EM93 \\
Rock name & $\begin{array}{c}\text { brucite } \\
\text { marble }\end{array}$ & $\begin{array}{c}\text { skarn } \\
\text { brucite } \\
\text { marble }\end{array}$ & $\begin{array}{c}\text { sketerneous } \\
\text { samples }\end{array}$ & $\begin{array}{c}\text { green } \\
\text { marble }\end{array}$ & $\begin{array}{c}\text { skarn } \\
\text { heterogeneous } \\
\text { samples }\end{array}$ & $\begin{array}{c}\text { skarn } \\
\text { with } \\
\text { zebra } \\
\text { stripes }\end{array}$ & skarn \\
\hline $\begin{array}{c}\text { calcite + dolomite } \\
\text { diopside }\end{array}$ & 57 & 58 & 85 & 15 & 10 & 39 & 6 & 56 & 0 \\
olivine + & 0 & 0 & 8 & 0 & 90 & 9 & 0 & 0 & 45 \\
serpentine & 1 & 2 & 2 & 0 & 0 & 15 & 0 & 39 & 0 \\
hydrogrossular & 0 & 0 & 5 & 0 & 0 & 5 & 26 & 3 & 0 \\
brucite & 42 & 40 & 0 & 0 & 0 & 0 & 0 & 0 & 0 \\
prenhite & 0 & 0 & 0 & 0 & 0 & 0 & 0 & 0 & 10 \\
spinel & 0 & 0 & 0 & 0 & 0 & 0 & 0 & 1 & 0 \\
oxide/sulfides & 0 & 0 & 0 & 1 & 0 & 5 & 0 & 1 & 7 \\
epidote & 0 & 0 & 0 & 0 & 0 & 22 & 41 & 0 & 23 \\
phlogopite & 0 & 0 & 0 & 15 & 0 & 0 & 21 & 0 & 0 \\
chlorite & 0 & 0 & 0 & 45 & 0 & 0 & 0 & 0 & 0 \\
apatite & 0 & 0 & 0 & 3 & 0 & 0 & 0 & 0 & 0 \\
quartz & 0 & 0 & 0 & 21 & 0 & 0 & 6 & 0 & 0 \\
andradite & 0 & 0 & 0 & 0 & 0 & 0 & 0 & 0 & 15 \\
wollastonite & 0 & 0 & 0 & 0 & 0 & 5 & 0 & 0 & 0 \\
\hline total & 100 & 100 & 100 & 100 & 100 & 100 & 100 & 100 & 100 \\
\hline grain size (mm) & $0.5-3$ & $0.5-3$ & $0.4-2.5$ & $0.1-0.5$ & $0.5-0.9$ & $0.5-4$ & $0.2-2$ & $0.1-6$ & $0.3-15$ \\
Structure/texture & isotrope & isotrope & isotrope & banded & banded & banded & isotrope & stripes & isotrope \\
\hline \hline
\end{tabular}

Table 5 Composition of liquids used in petrologic models compared with the bulk composition of the Panzhihua intrusion.

\begin{tabular}{cccc} 
& $\mathrm{YL}-2^{*}$ & $\mathrm{YL}-2 \mathrm{E}^{* *}$ & $\begin{array}{c}\text { Average } \\
\text { composition of } \\
\text { the Panzhihua } \\
\text { intrusion*** }\end{array}$ \\
\hline $\mathrm{SiO}_{2}$ & 45.7 & 47.5 & 42.6 \\
$\mathbf{A l}_{2} \mathbf{O}_{3}$ & 13.2 & 14.0 & 15.8 \\
$\mathrm{FeO}_{\text {tot }}$ & & & 15.6 \\
$\mathrm{Fe}_{2} \mathbf{O}_{3 \text { tot }}$ & 13.2 & 13.5 & \\
$\mathrm{MnO}$ & 0.2 & 0.0 & \\
$\mathrm{MgO}$ & 8.1 & 7.1 & 5.99 \\
$\mathbf{C a O}$ & 9.9 & 10.6 & 11.9 \\
$\mathrm{Na}_{2} \mathbf{O}$ & 2.5 & 2.7 & 2.45 \\
$\mathrm{~K}_{2} \mathbf{O}$ & 1.6 & 1.7 & 0.31 \\
$\mathrm{TiO}_{2}$ & 2.6 & 2.7 & 3.99 \\
$\mathbf{P}_{2} \mathbf{O}_{5}$ & 0.3 & 0.3 & 0.69 \\
$\mathbf{L O I}$ & 2.3 & & \\
\hline \hline total & 99.6 & 100.0 & 99.2 \\
\hline \hline
\end{tabular}

*composition of a basalt from Song et al. (2001)

**estimation of the composition of the evolved magma, produced by

$3.6 \%$ crystallisation of the YL-2 basalt (calculated with PELE)

***bulk composition of the Panzhihua intrusion (Zhou et al. 2005) 


\section{FIGURES}

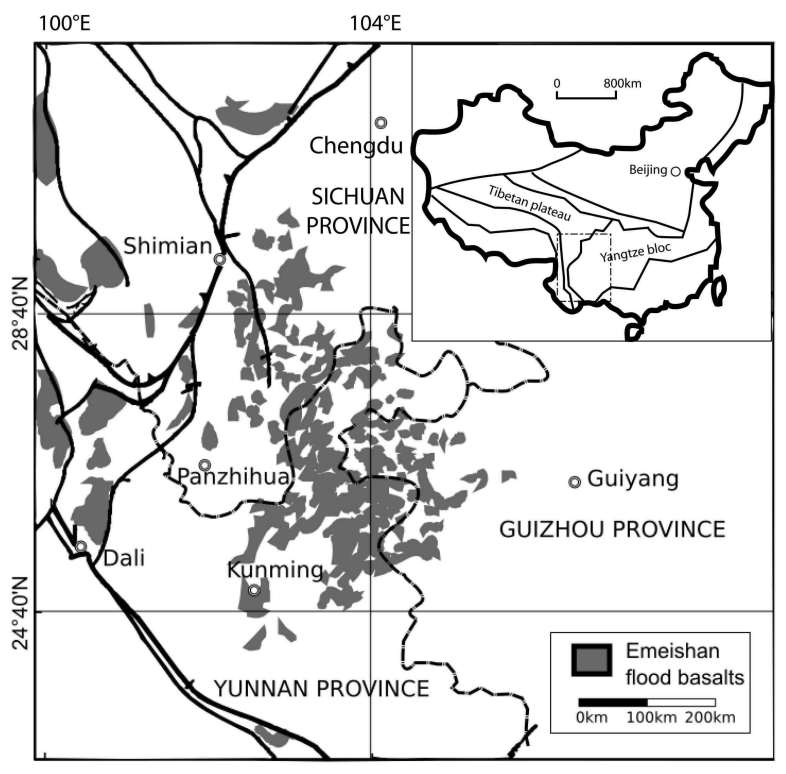

Figure 1.

(a)

\begin{tabular}{|c|c|c|c|}
\hline \multirow{6}{*}{ 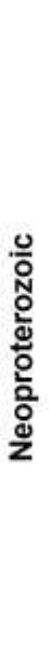 } & \multirow{2}{*}{$\frac{\frac{5}{\pi}}{\frac{\pi}{n}}$} & $\begin{array}{l}\text { Dengying } \\
\text { Formation } \\
\left(Z_{2} d, Z_{2} g\right)\end{array}$ & $\begin{array}{l}\text { dolomite with phosphate and sulfur } \\
\text { dolomite intercalated } \\
\text { with chert nodules } \\
\text { silicious limestone } \\
\text { silicious oolithic dolomitic }\end{array}$ \\
\hline & & $\begin{array}{c}\text { Doushantuo } \\
\text { Formation } \\
\left(Z_{2} \text { bss }\right)\end{array}$ & $\begin{array}{l}\text { dolomite intercalated with } \\
\text { sandstone, conglomerate } \\
\text { and black shale }\end{array}$ \\
\hline & \multirow{4}{*}{$\frac{\text { 至 }}{\frac{\text { d }}{2}}$} & $\begin{array}{l}\text { Nantuo } \\
\text { Formation }\end{array}$ & tillite \\
\hline & & $\begin{array}{l}\text { Datangpo } \\
\text { Formation }\end{array}$ & siltstone, mudstone and limestone \\
\hline & & $\begin{array}{l}\text { Gucheng } \\
\text { Formation }\end{array}$ & tillite \\
\hline & & $\begin{array}{l}\text { Liantuo } \\
\text { Formation }\end{array}$ & sandstone with volcanic clasts \\
\hline
\end{tabular}

(b)

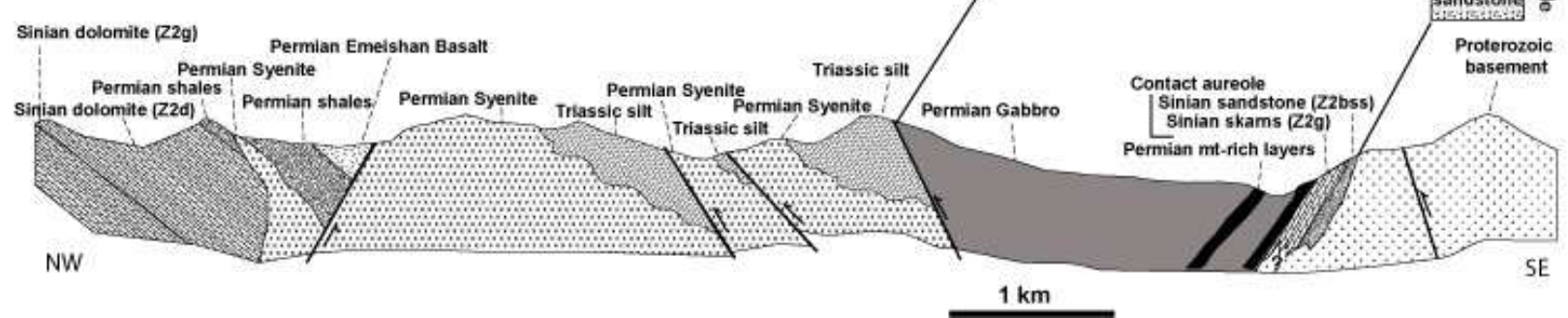

Figure 2 


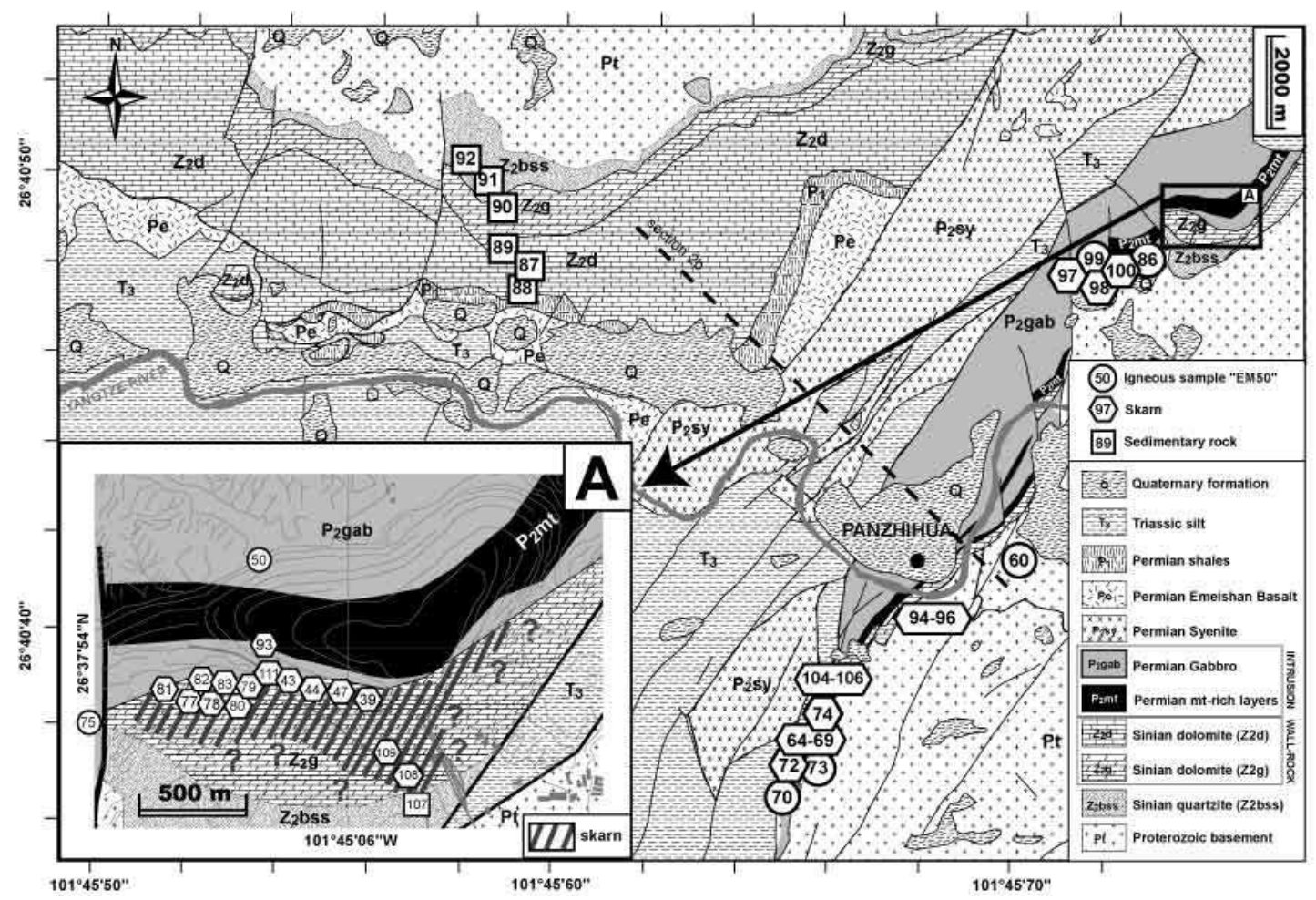

Figure 3. 

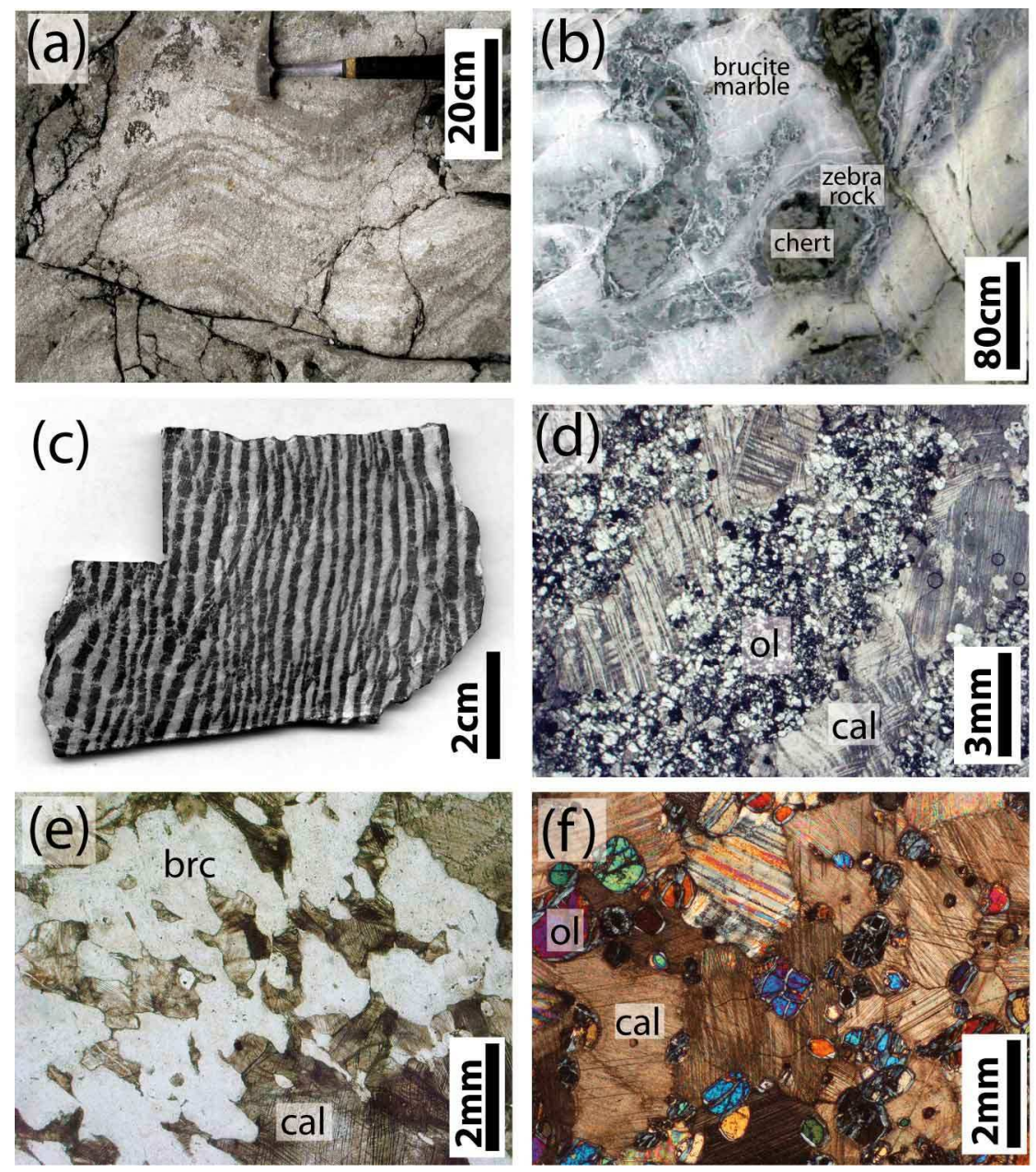

Figure 4. 

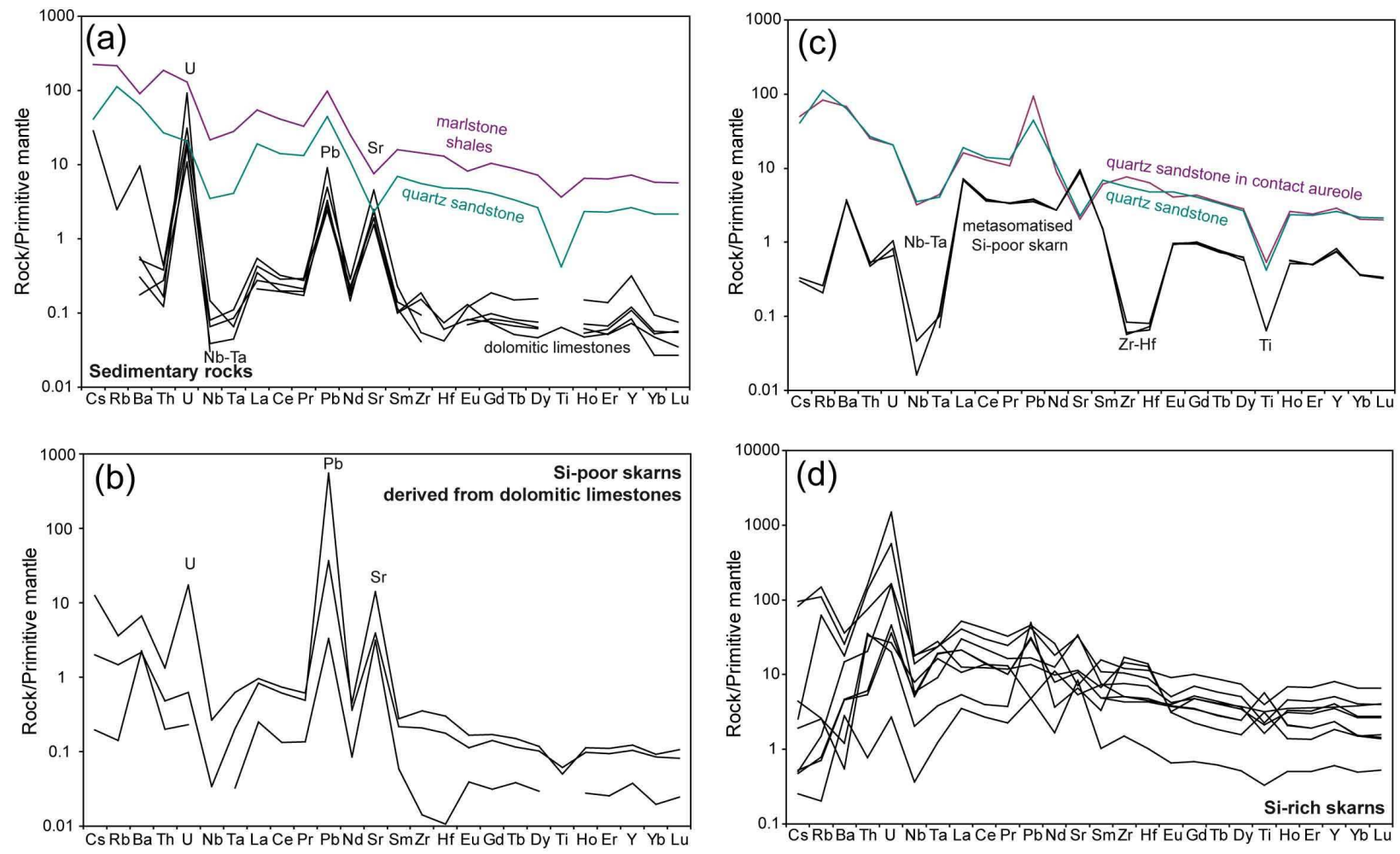

Figure 5. 

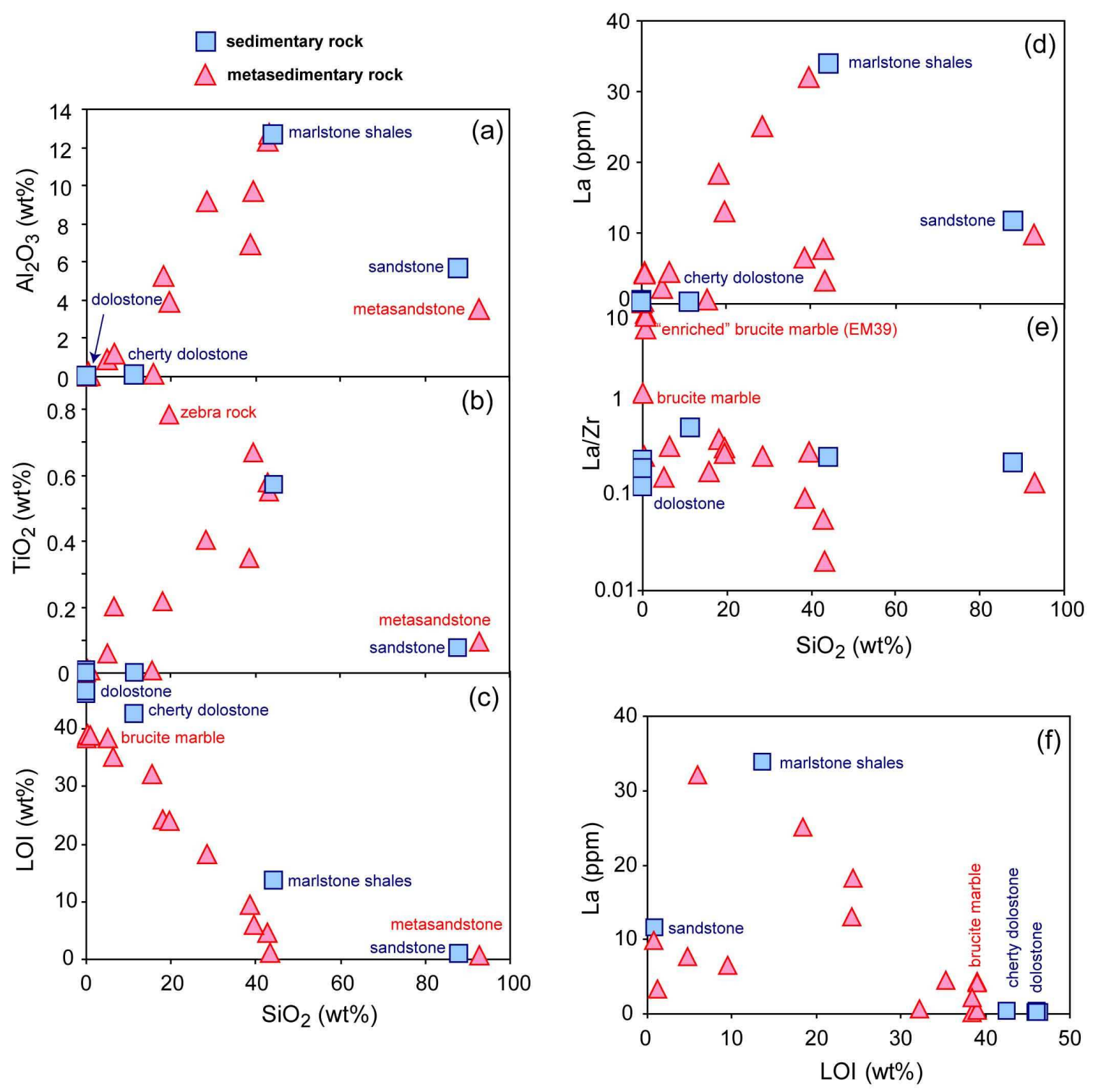

Figure 6. 

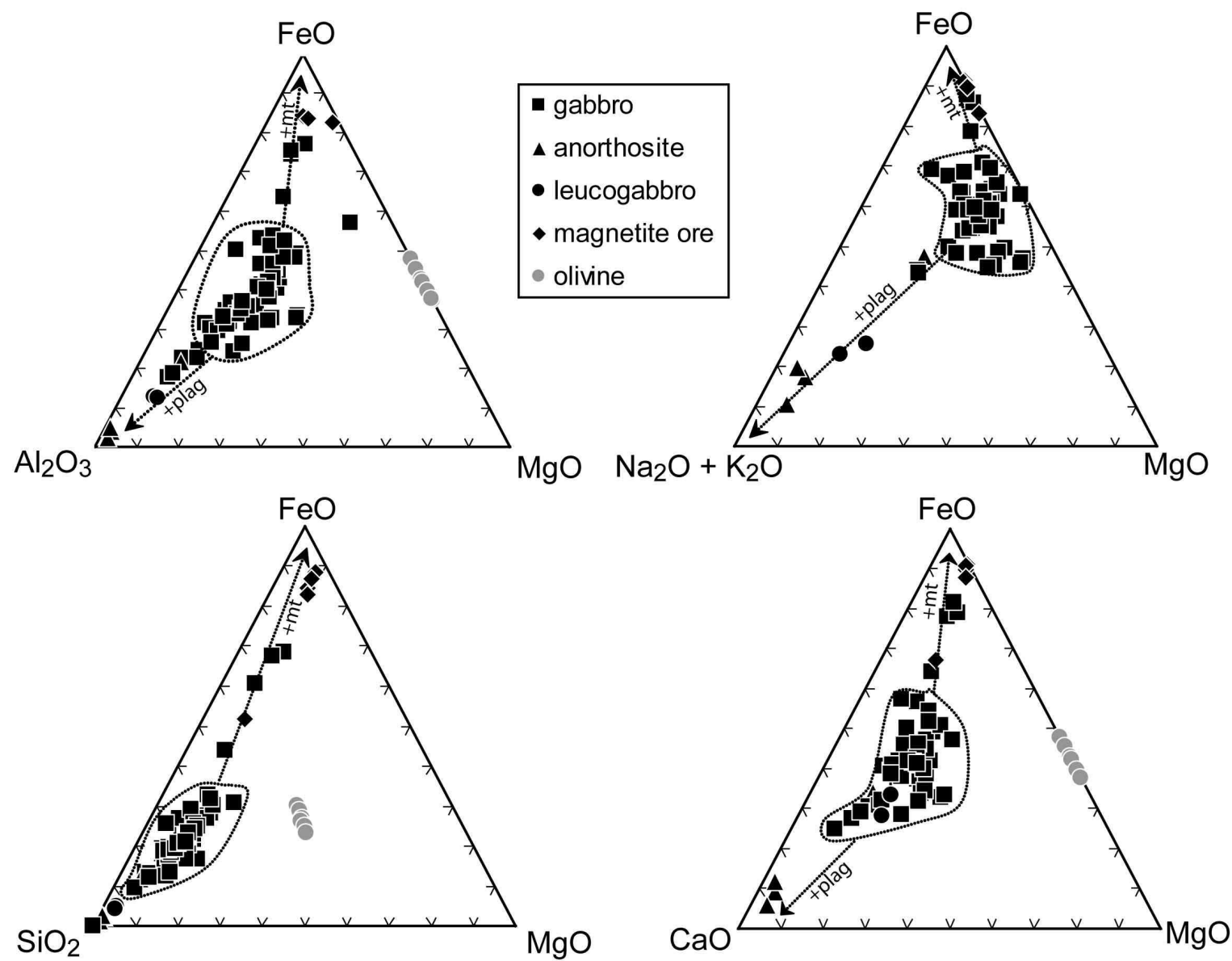

Figure 7. 

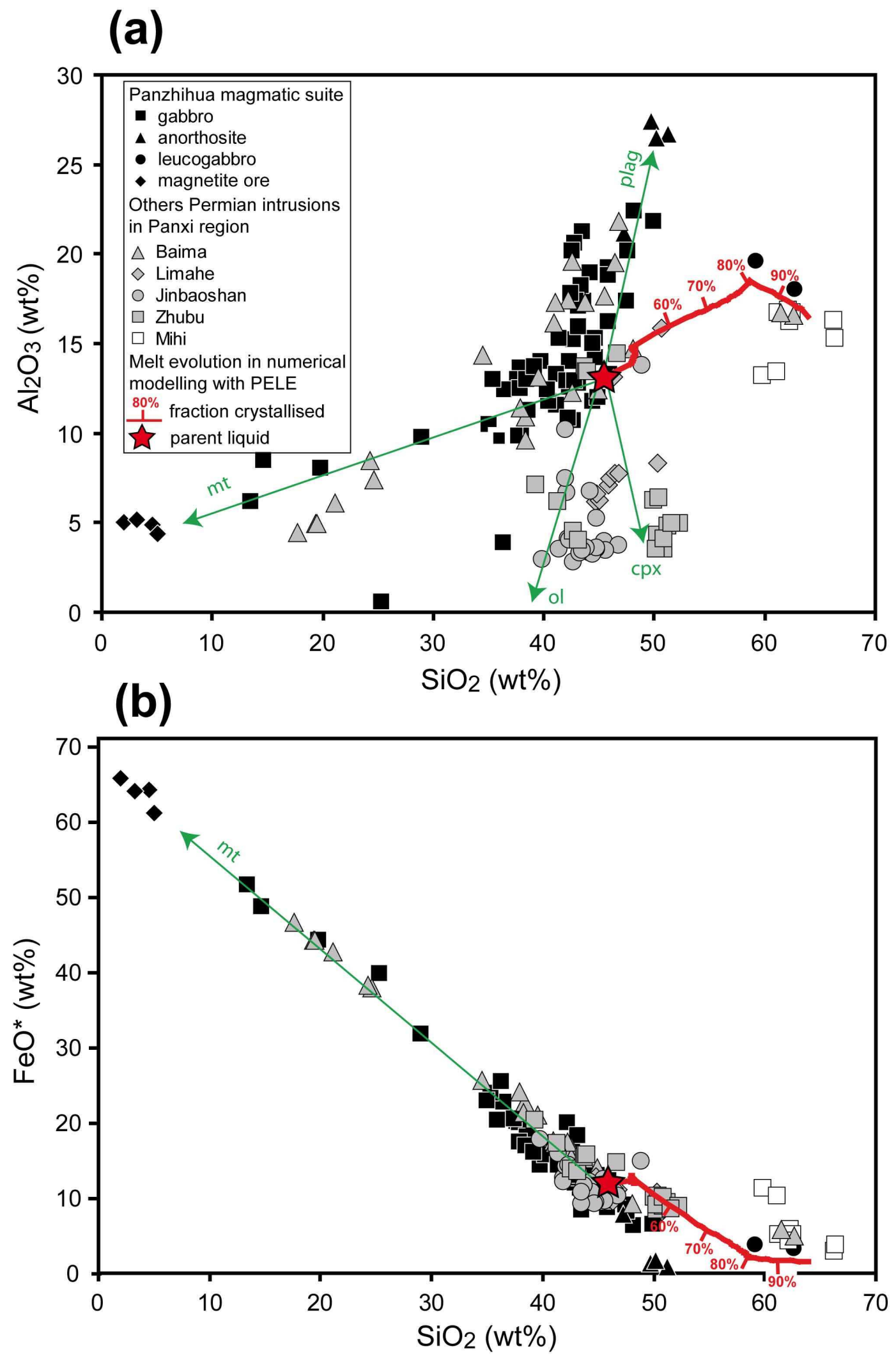

Figure 8. 


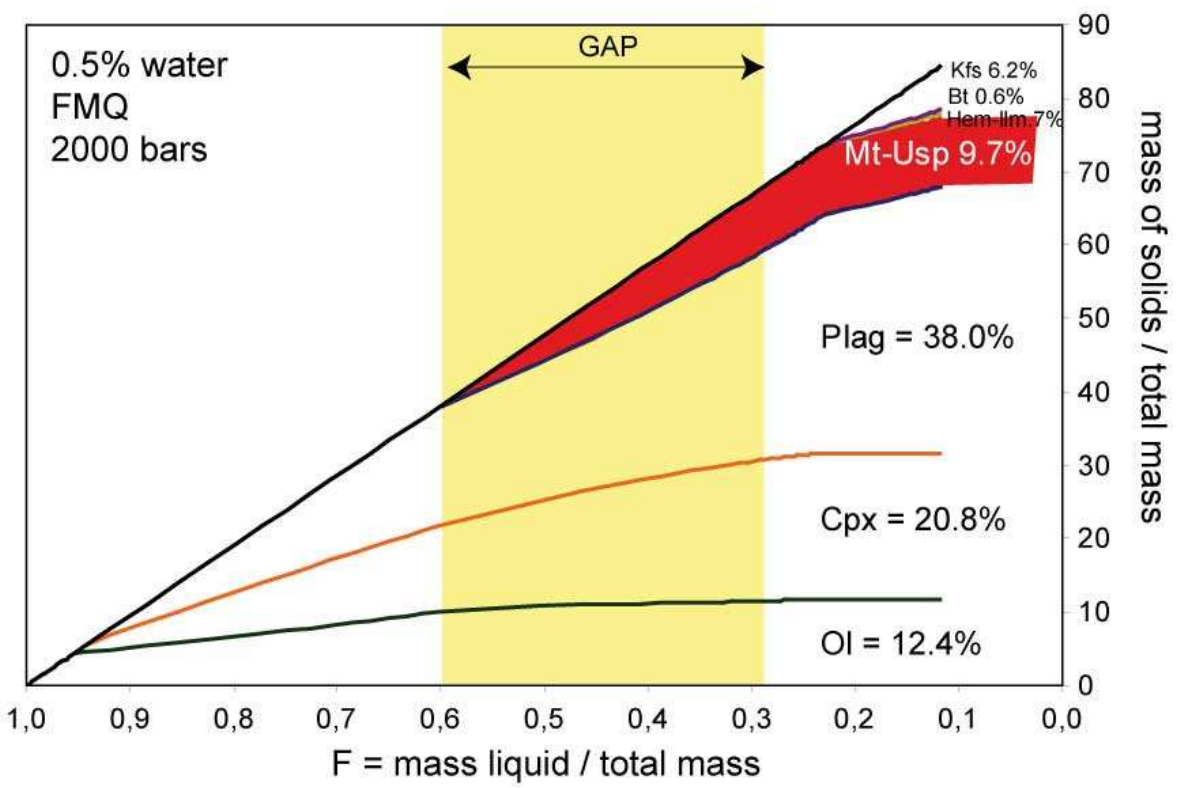

Figure 9.

(a)

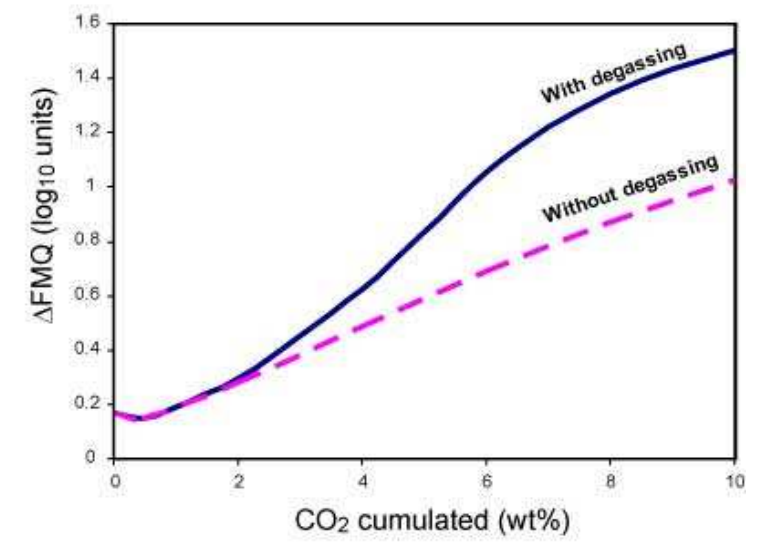

(b)

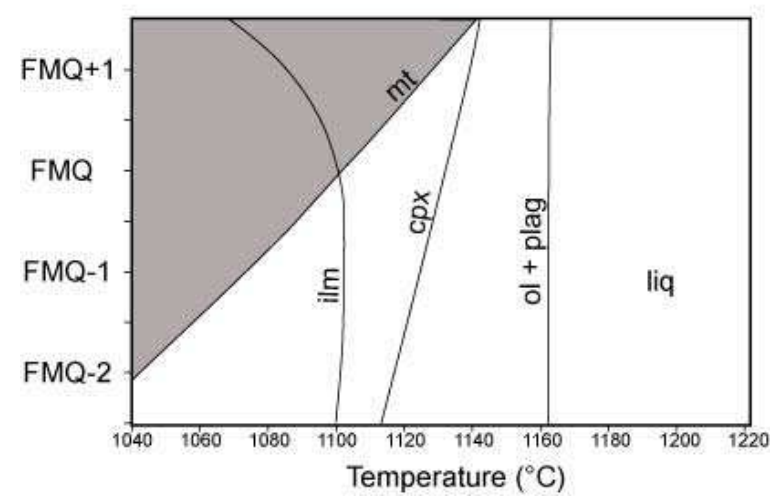

Figure 10. 